\title{
IGNIS, INCENDIUM, FORTUITUS CASUS - D. 19, 2, 9, 3 I OPASNOST ŠTETE OD POŽARA KOD LOCATIO FUNDI
}

Sažetak:

\begin{abstract}
U radu se raspravlja o sadržaju i značenju Ulpijanova teksta D. 19, 2, 9, 3 u analizi problema podjele rizika kod ugovora o zakupu i položaju požara među različitim pojavama koje se u rimskim pravnim izvorima navode kao oblici više sile. U okviru razmatranja naknadne nemogućnosti ispunjenja činidbe kod locatio conductio (rei), tekst D. 19, 2, 9, 3 ističe se kao jedini u vezi s locatio fundi u kojem se spominje periculum, no koji je opterećen problemom suprotstavljenih tumačenja. $U$ radu se polazi od raščlambe predmetnog teksta te ga se postavlja u kontekst drugih fragmenata u kojima su rimski pravnici izložili rješenja u vezi sa štetom od požara kod zakupa koji su analizirani u radu. Zaključno se iznose stavovi o sadržaju i funkciji teksta te diferenciranom pristupu požaru kao obliku više sile.
\end{abstract}

Ključne riječi: $\quad$ ignis, incendium, fortuitus casus, vis maior, locatio conductio, požar

\section{UVOD}

Razmatrajući različite okolnosti zbog kojih je dolazilo do nemogućnosti ispunjenja obveza stranaka iz ugovora o najmu ili zakupu (locatio conductio rei) u rimskom pravu, može se uočiti da su požari bili jedan od češćih uzroka uništenja predmeta ugovora o najmu ili zakupu. ${ }^{1}$ To je razumljivo s obzirom na relativno česte požare u Rimu, ${ }^{2}$ povezane uz korištene građevne materijale, gustoću i visinu zgrada te uske ulice, brojna skladišta u gradu ili na rubovima grada

Dr. sc. Tomislav Karlović, izvanredni profesor Pravnog fakulteta Sveučilišta u Zagrebu, Trg Republike Hrvatske 3, 10000 Zagreb. E-adresa: tkarlovi@pravo.hr. ORCID: https://orcid.org/0000-0003-1846-1318.

1 Uz tekstove obrađene infra u radu iz titula D. 19, 2 također možemo navesti sljedeće paragrafe (s obzirom na to da su iz određenih fragmenata analizirani samo pojedini paragrafi): D. 19, 2, 15, 3 (Ulpianus 32 ad edictum); D. 19, 2, 19, 6 (Ulpianus 32 ad edictum), D. 19, 2, 30, 1 (Alfenus 3 a Paulo epitomarum). Usp. Theo Mayer-Maly, Locatio conductio (Verlag Herold 1956) 190 i sl. 
s lako zapaljivim stvarima, sve elemente koji su pogodovali brzom širenju vatre. ${ }^{3}$ U jednakoj mjeri, a možda i više, rizik štete od požara bio je prisutan pri zakupu seoskih imanja, i glede kuća i gospodarskih zgrada, i usjeva. ${ }^{4}$ Riječ je o opasnosti koja je prijetila izvana, u obliku vatrene stihije, nepredvidljive nekontrolirane sile iz nepoznatog izvora od koje se teško obraniti, no također i kao inherentni rizik vezan uz držanje peći i ognjišta na imanju iz kojih se nepredviđeno mogla proširiti buktinja.

Požar, incendium ${ }^{5}$, općenito je svrstavan među oblike više sile, ${ }^{6}$ međutim, s obzirom na navedenu dvostrukost mogućih izvorišta, postojale su situacije u kojima se njegov nastanak mogao pripisati jednoj od ugovornih strana. Uz opću odgovornost za naknadu štete zbog oštećenja ili uništenja stvari, ${ }^{7}$ glede čega je trebalo utvrditi ispunjenje pretpostavaka za podizanje actio (utilis) legis Aquiliae, ${ }^{8} \mathrm{u}$ slučaju da je imanje dano u zakup te su zakupnik odnosno zakupnikovi robovi, kako navodi primjerice Ulpijan u D. 9, 2, 27, 9 i 11 (Ulpianus 18 ad edictum) pozivajući se na Neracija i Prokula, izazvali požar, za vlasnika je postojala mogućnost izbora između podizanja actio locati i actio legis Aquiliae. ${ }^{9}$

3 U vezi s požarom, zaštitom od požara te pravnom regulacijom protupožarnih mjera usp. OF Robinson, Ancient Rome: City Planning and Administration (Routledge 1994) 90 i sl.; Robert Sablayrolles, Libertinus miles. Les cohortes de vigiles (École Française de Rome, 1996) 5 i sl.; Luciano Minieri, 'Normative Antincendio in Diritto Romano Tardo Classico e Postclassico' (2004) 1(13) IVS ANTIQVVM Drevnee pravo 83 i sl.; Piotr Kołodko, 'The Powers and Significance of the Prefect of the 'Vigiles' ('praefectus vigilum') in Ancient Rome' (2012) 12(4) Zeszyty Prawnicze 199 i sl. Također vidi Geoffrey MacCormack, 'Criminal Liability for Fire in Early and Classical Roman Law' (1972) 3 Index. Quaderni camerti di studi romanistici 382 i sl.; JS Rainbird, The Vigiles of Rome (Durham theses 1976); OF Robinson, 'Fire prevention at Rome' (1977) 24 Revue internationale des droits de l'antiquite 377 i sl.; BW Frier, Landlords and Tenants in Imperial Rome (Princeton University Press 1980) 21 i sl.; Bronislaw Sitek, 'Criminal Liability of 'incendiarii' in Ancient Roman Law' (2007) 6 Diritto e Storia, dostupno na: <http://www.dirittoestoria. it/6/Rassegne/Sitek-Incendiarii-ancient-Roman-Law.htm> pristupljeno 25. siječnja 2021.; Paul du Plessis, 'Notes on a fire' u Fritz Sturm, Thomas Philip i Otto Jochen (eds), Liber Amicorum Guido Tsuno (Vico 2013) 277 i sl.

4 Primjerice vidi u okviru razmatranja zakupa seoskih imanja PJ du Plessis, Letting and Hiring in Roman Legal Thought: 27 BCE - 284 CE (Brill 2012) str. 141 i sl. U vezi s činjenicom da tekstovi u prvom redu obrađuju problem šteta od požara kod zakupa seoskih imanja, kao opći naziv širokog značenja za razne situacije obrađene u radu uzet je locatio fundi. U vezi s fundus vidi ibid, 142 i sl.

5 Glede pojma incendium usp. Georg Kleinfeller, 'Incendium' u Paulys Realencyclopädie der classischen Altertumswissenschaft, IX, 2 Halbband 18 (Mezler 1918) 1244-1245; Mirko Divković, Latinsko-hrvatski rječnik (Dunja, 2006) 508.

6 Vidi Theo Mayer-Maly, 'Höhere Gewalt: Falltypen und Begriffsbildung' u Festschrift für Arthur Steinwenter zum 70. Geburtstag (Böhlau 1958) 64 i sl.; Wolfgang Ernst, 'Wandlungen des 'vis maior'-Begriffes in der Entwicklung der römischen Rechtswissenschaft' (1994) 22 Index. Quaderni camerti di studi romanistici 293 i sl.; Jean-Francois Gerkens '"Vis maior" and "vis cui resisti non potest"' u Rena van den Bergh i Gardiol van Niekerk (eds) Ex iusta causa traditum. Essays in honour of Eric H. Pool (University of South Africa 2005) 113 i sl.

7 U ovoj prilici neće se ulaziti u pitanje javnopravne regulacije te u problem odnosa kaznenopravne odgovornosti u slučaju podmetanja požara dolo na zgradi u gradu te građanskopravne odgovornosti zbog uništenja ili oštećenja stvari u drugim slučajevima podmetanja požara, npr. na kući ili voćnjaku, a u vezi s Coll. 12, 7, 1-3, odnosno D. 9, 2, 27, 7-8 (Ulpianus 18 ad edictum) i D. 48, 8, 10 (Ulpianus 18 ad edictum) te drugima, glede čega, s uputom na daljnju literaturu, uz djela navedena u bilj. 3 vidi i: Luciano Minieri, 'Sul quasi incendiarius' (2011) 58 Revue internationale des droits de l'antiquité 250 i sl.; du Plessis (n 3) 282 i sl.

8 Općenito o pretpostavkama podizanja actio legis Aquiliae, s uputom na daljnju literaturu, vidi: Vincenzo Arangio-Ruiz, Istituzioni di diritto romano (14th ed., Jovene 1960) 373 i sl.; Max Kaser, Das römische Privatrecht, I, Das altrömische, das vorklassische und klassische Recht (2. Aufl., Beck'sche Verlagsbuchhandlung 1971) 609 i sl.; Mario Talamanca, Istituzioni di diritto romano (14. ed., Giuffrè 1990) 625 i sl.; Reinhard Zimmermann, The Law of Obligations: Roman Foundations of the Civilian Tradition (Oxford University Press 1992) 953 i sl.; Herbert Hausmaninger, Das Schadenersatzrecht der lex Aquilia (5. Aufl., Manzsche Verlags- und Universitätsbuchhandlung 1996); Antonio Guarino, Diritto privato romano (12. ed., Jovene 2001) 972 i sl.; Pascal Pichonnaz, Les fondements romains du droit privé (Schulthess 2008) 525 i sl. (s recentnijim i opsežnim popisom literature); AJB Sirks, 'Delicts' u David Johnston (ed), The Cambridge Companion to Roman Law (Cambridge University Press 2015) str. 258 i sl. Također usp. Ante Romac, Rimsko pravo (Narodne novine 1994) 346 i sl.; Marijan Horvat, Rimsko pravo (Pravni fakultet Sveučilišta u Zagrebu 2017) 382 i sl.; Samir Aličić, Imovinska šteta u rimskom klasičnom pravu (University Press 2017).

9 Glede tekstova usp. BW Frier, 'Tenant’s Liability for Damage to Landlord’s Property in Classical Roman Law' (1978) 95 Zeitschrift der Savigny-Stiftung für Rechtsgeschichte. Romanistische Abteilung (dalje: SZ RA) 256 i sl.; Riccardo Fercia, La responsabilità per fatto di ausiliari nel diritto romano (CEDAM 2008) 72 i sl., 107 i sl. Također, općenito o odnosu actio legis Aquiliae i tužbi iz ugovora, 
U slučaju izbora actio locati trebalo je ispitati bi li zakupoprimac odgovarao, što je, kako upućuju izvori koje ćemo analizirati u radu, bilo podložno različitim tumačenjima ovisno o konkretnim okolnostima i sadržaju ugovora. To nas dovodi i do glavne teme rada, problema odgovornosti za štetne posljedice požara kod ugovora o zakupu zemljišta, pri čemu je u fokusu i polazište razmatranja Ulpijanov tekst D. 19, 2, 9, 3 (Ulpianus 32 ad edictum). Riječ je o komentaru koji se ističe kao jedini u vezi s locatio fundi u kojem se spominje periculum, no glede čijeg točnog sadržaja i značenja postoje bitna razilaženja u literaturi. Njegovim postavljanjem u kontekst drugih fragmenata u kojima su rimski pravnici izložili rješenja u vezi sa štetom od vatre i požara kod locatio conductio rei, a koji su ovdje analizirani, cilj je izvući zaključke i konkretno u vezi s njegovim izvornim sadržajem i općenito o utjecaju požara na obveze iz zakupa. Također, u okviru predmetne raščlambe, bit će obrađen odnos ignis i incendium s obzirom na koncept fortuitus casus.

\section{D. 19, 2, 9, 3 - NON PRAESTABIT PERICULUM LOCATOR ILI LOCATORI?}

Problem podjele rizika kod ugovora o zakupu u rimskom pravu u prvom se redu obrađuje na temelju Ulpijanova teksta D. 19, 2, 15, 2 (Ulpianus 32 ad edictum) i Servijeve distinkcije prema kojoj je zakupodavac, locator, snosio štetne posljedice više sile. ${ }^{10}$ Navedeni tekst je već šire obrađen na drugom mjestu iz aspekta problema promjene okolnosti, ${ }^{11}$ međutim, sam pericu-

s uputom na daljnju literaturu, vidi Detlef Liebs, Die Klagenkonkurrenz im römischen Recht (Vandenhoeck \& Ruprecht 1972) (za fragmente vidi str. 120 i 210); Giullieta Rossetti, Alle origini della moderna responsabilità extracontrattuale. L'actio ex lege Aquilia tra "natura penale" e "funzione reipersecutoria" Forum historiae iuris, 22. Mai 2020, dostupno na: <https://forhistiur.net/2020-05rossetti/> pristupljeno 26. siječnja 2021. Vidi i infra bilj. 65-67.

10 Iz opsežne literature mogu se navesti sljedeća djela i članci: Mayer-Maly (n 1) 140 i sl.; Max Kaser, 'Periculum locatoris' (1957) 74 SZ RA 155 i sl.; Juan Miquel, 'Periculum locatoris' (1964) 81 SZ RA 173 i sl.; Antonio Masi, 'Il problema della remissione della mercede nella locazione di fundi rustici all luce di una testimonianza di Columella' u Studi in memoria di Giuliana D’Amelio, vol. I, (Giuffrè 1978) 273 i sl.; Francesco Sitzia, 'Considerazioni in tema di periculum locatoris e di remissio mercedis' u Studi in memoria di Giuliana D’Amelio, vol. I (Giuffrè 1978) 331 i sl.; Nicola Palazzolo, Saggi in materia di locazione (Libreria Editrice Torre 1995) 105 i sl.; Imre Molnár, 'Verantwortung und Gefahrtragung bei der locatio conductio zur Zeit des Prinzipats' u Hildegard Temporini i Wolfgang Haase (eds) Aufstieg und Niedergang der römischen Welt, vol. II, 14, (de Gruyter 1982) 583 i sl.; PW de Neeve, 'Remissio mercedis' (1983) 100 SZ RA 296 i sl.; Paolo Pinna Parpaglia, Vitia ex ipsa re. Aspetti della locazione in diritto romano (Giuffrè 1983); Wolfgang Ernst, 'Das Nutzungsrisiko bei der Pacht' (1988) 105 SZ RA 541 i sl.; Bruce Frier, Law, Economics, and Disasters Down on the Farm: 'Remissio Mercedis' Revisited (1989-1990) 31-32 Bullettino dell'Istituto di diritto romano 237 i sl.; Riccardo Cardilli, L'obbligazione di "praestare" e la responsabilità contrattuale in diritto romano (II sec. A.C. - II sec. D.C.) (Giuffrè 1995) 229 i sl.; DP Kehoe, Investment, Profit, and Tenancy. The Jurists and the Roman Agrarian Economy (The University of Michigan Press 1997) 225 i sl.; Roberto Fiori, La Definizione dell 'locatio conductio', Giurisprudenza romana e tradizione romanistica (Jovene 1999) 108 i sl.; CH Müller, Gefahrtragung bei der locatio conductio. Miete, Pacht, Dienst- und Werkvertrag im Kommentar römischer Juristen (Schöningh 2002) 25 i sl.; PJ du Plessis, A History of remissio mercedis and related legal institutions (Dphil thesis, Rotterdam 2003) 26 i sl.; Luigi Capogrossi Colognesi, Remissio mercedis. Una storia tra logiche di sistema e autorità della norma (Jovene 2005) 5 i sl.; JD Harke, Locatio conductio, Kolonat, Pacht, Landpacht (Duncker \& Humblot 2005) 14 i sl.; Dennis Kehoe, Law and Rural Economy in the Roman Empire (The University of Michigan Press 2007) 109 i sl.; Pascal Pichonnaz, 'De la "clausula rebus sic stantibus" au "hardship", Aspects d'une évolution du rôle du juge' u Annette Ruelle i Maxime Berlingin (eds), Le droit romain d'hier à aujourd'hui, Collationes et oblationes, Liber amicorum en l'honneur du professeur Gilbert Hanard (Publications des Facultés Universitaires Saint-Louis 2009) 157 i sl.; Roberto Fiori, 'Bona fides' u Roberto Fiori (ed), Modelli teorici e metodologici nella storia del diritto privato, vol. IV (Jovene 2011) 145 i sl.; Andreja Katančević, 'Vis maior i locatio conductio fundi' (2013) 61(2) Anali Pravnog fakulteta u Beogradu 215 i sl.; DP Kehoe, 'Tenure of Land and Agricultural Regulation' u PJ du Plessis, Clifford Ando i Kaius Tuori (eds.), The Oxford Handbook of Roman Law and Society (Oxford University Press 2016) 650 i sl.

11 Vidi Tomislav Karlović i Andrea Balić, 'Remissio mercedis i utjecaj promijenjenih okolnosti na obveze iz ugovora o zakupu u rimskom pravu' (2020) 57(4) Zbornik Pravnog fakulteta u Splitu 957 i sl. 
lum kao općeniti pojam kojim se u ugovornim odnosima upućivalo na opasnost nastanka štete, odnosno snošenja rizika i/ili odgovornosti za štetu koja je u prvom redu nastala bez krivnje ijedne stranke, šireg je značenja te obuhvaća opsežniji kompleks pitanja. ${ }^{12} \mathrm{Uz}$ to, kroz mišljenja pravnika i koncept periculum je evoluirao od pretklasičnog do kasnog klasičnog prava. ${ }^{13}$

U samom titulu D. 19, 2 (Locati conducti), u kojem su obrađene tužbe iz locatio conductio, periculum se uglavnom javlja u tekstovima o locatio conductio operis. Riječ je u situacijama u kojima je conductor odgovarao za slučajno uništenje predmeta ugovora dok je stvar bila kod njega, odnosno dok je radio na njoj. ${ }^{14}$ Pritom, conductor u pravilu i nije odgovarao za periculum, osim ako se posebno obvezao (D. 19, 2, 13, 5 (Ulpianus 32 ad edictum)), ${ }^{15}$ ili su njegovi zaposlenici skrivili štetu (D. 19, 2, 25, 7 (Gaius 10 ad edictum provinciale)), ${ }^{16}$ ili je bila riječ o isporuci djela per aversionem ili u cijelosti (D. 19, 2, 36 (Florentinus 7 institutionum), D. 19, 2, 59 (Iavolenus 5 ex posterioribus Labeonis) i D. 19, 2, 62 (Labeo 1 pithanon)), ${ }^{17}$ ili je bila riječ o izričitom primitku stvari u kustodiju (D. 19, 2, 40 (Gaius 5 ad edictum provinciale)). ${ }^{18}$ Glede locatio conductio rei periculum se spominje tek u D. 19, 2, 9, 3 (Ulpianus 32 ad edictum) te u D. 19, 2, 60, 6 (Labeo 5 posteriorum a Iavoleno epitomatorum), u potonjem u vezi s najmom skladišta. ${ }^{19}$

12 Uz djela navedena u bilj. 10, opširnije o temi vidi u: Vincenzo Arangio-Ruiz, Responsabilità Contrattuale in Diritto Romano (2. ed., Jovene 1933) 100 i sl.; Emilio Betti, '”Periculum”. Problema del rischio contrattuale in diritto romano classico e giustianeo', u Studi in onore di Pietro de Francisci, vol. I., (Giuffrè 1956) 131 i sl.; Geoffrey MacCormack, 'Periculum' (1979) 96 SZ RA 129 i sl.; CA Cannata, Sul problema della responsabilità nel diritto privato romano (Libreria Editrice Torre 1996) 81 i sl.

13 Primjerice za locatio conductio, s uputom na daljnju literaturu, uz djela u prethodnoj bilješci vidi i Paul du Plessis, 'Liability', 'risk' and locatio conductio' u Roberto Fiori (ed), Modelli teorici e metodologici nella storia del diritto privato, vol. IV (Jovene 2011) 82 i sl.

14 Usp. MacCormack (n 12) 141 i sl.; Cardilli (n 10) 337 i sl.; du Plessis (n 10) 40 i sl.

15 Za ugovaranje oslobođenja od odgovornosti za periculum usp. D. 9, 2, 27, 29 (Ulpianus 18 ad edictum). Glede oba teksta usp. Pinna Parpaglia (n 10) 85 i sl. Također možemo upozoriti na širi popis tekstova izvan titula D. 19, 2 u kojima se pojavljuje odgovornost za periculum u vezi s locatio conductio kod MacCormacka, koji pritom navodi i D. 9, 2, 27, 29, D. 39, 2, 21, D. 40, 12, 13, 1, D. 47, 2, 12 pr., D. 47, 2, 14, 16, D. 50, 12, 1, 6, kao i C. 4, 65, 1 i 4 te tekstove koji se odnose na nautae poput D. 4, 9, 3 pr., D. 4, 9, 4 pr., D. 47, 5, 1, 4 i D. 47, 2, 14, 17. Usp. MacCormack (n 12) 142, bilj. 50.

16 Glede teksta koji je u prvom redu predmet obrade s obzirom na odgovornost pomoćnika primjerice vidi u: Geoffrey MacCormack, 'Culpa in eligendo' (1971) 18 Revue internationale des droits de l’antiquité 533 i sl.; Rolf Knütel 'Die Haftung für Hilfspersonen im römischen Recht' (1983) 100 SZ RA 419 i sl.; Fercia (n 9) 285 i sl.

17 U sva tri slučaja je riječ o djelu, konkretnije o izgradnji kuće u D. 19, 2, 59 i D. 19, 2, 62. Pritom se u prvom od potonja dva teksta navodi da periculum tereti naručitelja djela jer je riječ o potresu. U D. 19, 2, 62 izvođač je trebao predati cjelokupno djelo te je sam snosio rizik slučajne štete, odnosno propasti onoga što je napravio do predaje naručitelju djela, ali ne ako je do štete došlo zbog nedostatka zemljišta. Za detaljniju analizu tekstova primjerice usp. Susan Martin, 'The Case of the Collapsing Watercourse: Builders' Responsibility for Damage in Classical Roman Law' (1986) 4(2) Law and History Review 423 i sl.; Cardilli (n 10) 337 i sl., 416 i sl.; Müller (n 10) 69 i sl.

18 U tekstu se navodi da je netko uzeo stvar u kustodiju, što se može dvojako tumačiti: ili da je primio stvar radi naplatnog čuvanja, što nam se čini vjerojatnijim, ili posebno se obvezavši da će odgovarati za kustodiju, što je također bilo moguće i svrhom bi se podudaralo s prvom opcijom. Usp. Molnár (n 10) 614 i sl.; René Robaye, L'obligation de garde. Essai sur la responsabilité contractuelle en droit romain (Publications des Facultés Universitaires Saint-Louis 1987) 125 i sl.; Carlo Pelloso 'Custodia, receptum e responsabilità contrattuale' (2016) 29 Seminarios Complutenses de Derecho Romano 270 i sl.

19 U D. 19, 2, 60, 6 riječ je o imatelju skladišta, locator horrearius s kojim se sklapa ugovor o najmu skladišta. Tekst glasi: "Locator horrei propositum habuit se aurum argentum margaritam non recipere suo periculo: deinde cum sciret has res inferri, passus est. Proinde eum futurum tibi obligatum dixi, ac si propositum fuit, remissum videtur." (Najmodavac skladišta imao je objavljeno da ne prima na svoj rizik novac, srebro ili bisere: no kad je znao da su te stvari unesene, toga se odrekao. Stoga sam rekao da će ti biti obvezan, jer i da je to rekao, uzet će se da je odustao od toga.). Vidi s tim u vezi i D. 19, 2, 60, 9, iako se u tom paragrafu spominje samo kustodija, ne i periculum. Vidi opširnije u: Robaye (n 18) 125 i sl.; Cardilli (n 10) 373 i sl.

Također, periculum se navodi u D. 19, 2, 27, 1, no u navedenom paragrafu treba ga tumačiti u smislu bijega zakupoprimca sa zemljišta zbog opće opasnosti od strane vojske, a ne u smislu bijega zbog opasnosti odgovornosti za štetu. Usp. Mayer-Maly (n 1) 217. 
U vezi s locatio fundi tako bi samo Ulpijanov D. 19, 2, 9, 3 izričito upućivao na periculum, rizik nastanka štete, u ovom slučaju zbog požara, no rješavajući ga suprotno odluci iz reskripta sadržanog u D. 19, 2, 15, 3, ${ }^{20}$ odnosno općenito suprotno Servijevoj uputi o dužnosti snošenja rizika više sile kako ju je Ulpijan prenio u D. 19, 2, 15, $2 .{ }^{21}$ Problem se pojavljuje zbog toga što u D. 19, 2, 9, 3 nije precizirano je li šteta nastala na zemljištu, kući, stajama i drugim pripatcima zemljišta, ili pak na usjevima, što je s obzirom na navedeni nesklad s drugim fragmentima motiv sumnji na interpolacije te izvor različitih tumačenja u literaturi. Njegov sadržaj, pri čemu su radi potpunosti te boljeg shvaćanja konteksta zajedno navedeni drugi i treći paragraf, glasi:

D. 19, 2, 9, 2-3 (Ulpianus 32 ad edictum) 2. Iulianus libro quinto decimo digestorum dicit, si quis fundum locaverit, ut etiam si quid vi maiori accidisset, hoc ei praestaretur, pacto standum esse. 3. Si colonis praediorum lege locationis, ut innocentem ignem habeant, denuntiatum sit, si quidem fortuitus casus ${ }^{22}$ incendii causam intulerit, non praestabit periculum locator: si vero culpa locatoris, quam praestare necesse est, damnum fecerit, tenebitur. ${ }^{23}$

Nakon što je u uvodu i prvom paragrafu D. 19, 2, 9 raspravljano pitanje odgovornosti lokatora u slučaju da najmoprimcu ili zakupoprimcu nije omogućena poraba ili korištenje predmeta ugovora do kraja dogovorenog roka, pri čemu su poglavito obrađene situacije kada se to dogodilo bez njegove krivnje te nije više postojala obveza plaćanja naknade za preostali period, ova dva paragrafa odnose se na posebne uglavke kojima su osnovni odnosi mogli biti modificirani. U drugom paragrafu Ulpijan tako prenosi Julijanovu potvrdu valjanosti uglavka kojim bi zakupoprimac preuzimao odgovornost i za štetu nastalu višom silom. Dok je inače rizik više sile snosio zakupodavac, ovdje je on ugovorno prebačen na zakupoprimca. Pritom, prema usporedbi sa D. 19, 2, 15, 2, iako u tekstu nije precizirano o kojoj bi šteti bila riječ, može se pretpostaviti da bi se to odnosilo na dužnost plaćanja zakupnine (merces) i u slučaju da su usjevi bili uništeni višom silom, no ne treba isključiti da bi se praestare odnosilo i na štete na imanju. ${ }^{24}$ Treći paragraf pak upućuje na drugi oblik lex locationis koji su stranke mogle ugovoriti - da zakupoprimac može držati "bezopasnu vatru”, koji je u biti bio ublažena varijanta

20 D. 19, 2, 15, 3 (Ulpianus 32 ad edictum) Cum quidam incendium fundi allegaret et remissionem desideraret, ita ei rescriptum est: $s$ praedium coluisti, propter casum incendii repentini non immerito subveniendum tibi est. (Kada je netko tvrdio da je poljoprivredno imanje (zemljište) izgorjelo te je tražio smanjenje zakupnine, ovako mu je odgovoreno u reskriptu: 'Ako si obrađivao zemljište, nije ti bezrazložno pomoći zbog nepredviđenog požara.') Prijevod prema: Tomislav Karlović, Liber casuum. Priručnik za vježbe iz rimskog obveznog prava (Pravni fakultet u Zagrebu 2017) 62-63.

21 Vidi opširnije u djelima navedenima u bilj. 10, odnosno u Karlović, Balić (n 11) 965 i sl.

22 Na fortuitus casus kao interpolaciju, i općenito i u ovom tekstu, upućuje Luzzatto, no u kasnijim komentarima teza većinom nije preuzeta. Usp. GI Luzzatto, Caso fortuito e forza maggiore come limite alla responsabilità contrattuale, vol. I (Giuffrè 1938) 218-219. Općenito o fortuitus kao interpoliranom dodatku uz casus može se usporediti i ranije Alfredo De Medio, 'Caso fortuito e forza maggiore in diritto romano' (1908) 20 Bullettino dell'Istituto di diritto romano 208 (zaključak nakon analize više tekstova, no među kojima nije onaj obrađen u tekstu) te Fritz Schulz, 'Die Haftung für das Verschulden der Angestellten im klassischen römischen Recht' (1911) 38 Grünhuts Zeitschrift 35, bilj. 77. U vezi s De Medijom i prigovorom besmislene tautologije izraza fortuitus casus može se spomenuti suprotstavljeno Behrensovo objašnjenje o raširenoj rimskoj praksi potvrđivanja termina istoznačnicama (npr. pactum conventum i sl.). Usp. Dietrich Behrens, Die vis maior und das klassische Haftungssystem (Dphil thesis, Giessen 1936) 57 i sl.

23 D. 19, 2, 9, 2-3: "2. Julijan u 15. knjizi Digesta kaže ako je netko dao u zakup zemljište uz uglavak da će se (zakupoprimac) odgovarati i ako se nešto dogodi uslijed više sile, takav uglavak je valjan. 3. Ako je zakupcima zemljišta u ugovornoj odredbi dano pravo da drže bezopasnu vatru, ako slučajno nastane požar, zakupodavac neće odgovarati za slučaj (slučajno nastalu štetu, periculum): ali ako je šteta nastala uslijed krivnje zakupodavca, za koju je nužno da odgovara, onda će odgovarati." Usp. Otto Lenel, Palingenesia Iuris Civilis, vol. 2 (Tauchnitz 1889) (repr. Vico 2006.) 637-638. 
uglavka o općenitoj zabrani držanja vatre koji se spominje niže u titulu i za koji ćemo vidjeti pobliže kasnije.

U situaciji opisanoj u trećem paragrafu, u okviru odnosa zasnovanog ugovorom o zakupu uz uglavak o dopuštenom održavanju bezopasne ili neškodljive vatre (ignem innocentem ${ }^{25}$ ), slučajno (fortuito casu) se razvio požar. Konkretno se ne navodi da je požar nastao iz "neškodljive vatre" koju bi zapalili koloni te bi se prema intulerit moglo pomisliti da je izvor izvanjski, međutim, s obzirom na samo postojanje pravnog pitanja vjerojatno je temelj požara upravo bila postojeća vatra kolona iz koje je buknuo požar. Katalizator nastanka požara nije naveden, a vrlo vjerojatno nije bio ni poznat. Važno je bilo samo da nije nastao zbog namjere ili nepažnje kolona na što upućuju riječi fortuito casu. Konačno, kao pravno rješenje, iznosi se da u navedenom slučaju rizik štete (periculum) od požara ne bi bio na zakupodavcu, odnosno on bi bio oslobođen odgovornosti. Na to je dodana rečenica, ograničenje, da bi on ipak odgovarao za štetu ako bi se to dogodilo njegovom krivnjom.

Osnovni problem ovako postavljenog predmeta razmatranja, a prema čitanju sadržanom u Florentini, jest da nije jasno o kojoj bi šteti bila riječ, što povlači niz pitanja, od toga na koji bi način zakupodavac trebao odgovarati (praestare) za štetne posljedice požara te zašto ovdje ne snosi rizik više sile kao u D. 19, 2, 15, 3, do toga kako tumačiti odgovor da bi on bio kriv za taj požar prema posljednjem dijelu rečenice, pri čemu polazimo od pretpostavke o izvorištu požara u ignis innocens i problema kako bi on uopće mogao skriviti širenje požara od vatre koju su držali koloni. ${ }^{26}$ Međutim, prema Vulgati, ali primjerice i sholiji jednog od antecessores, Stjepana (Stephanus), ${ }^{27}$ drugo bi čitanje umjesto non praestabit periculum locator glasilo non praestabitur periculum locatori ${ }^{\text {te bi }} \mathrm{u}$ drugoj rečenici umjesto riječi culpa locatoris bilo navedeno culpa conductoris. ${ }^{28}$ To bi više bilo u skladu s očekivanim tijekom ideje o odgovornosti nastavno na sam uglavak i nastanak požara, kao i vjerojatnijom posljedicom nastanka štete na stvarima zakupodavca, na kući i na zemljištu, o čemu govore i prethodni dijelovi teksta, ${ }^{29,30}$ no ne može se reći da je općenito prihvaćeno. Dapače, suprotnost dviju varijanti teksta izvor je razilaženja u literaturi glede tumačenja Ulpijanova rješenja.

Osnovna koncepcija teksta s oslobođenjem odgovornosti zakupodavca, koju prihvaćaju primjerice Luzzatto, Molnár i Thomas, ${ }^{31}$ u prvom redu se može objasniti time da bi bila riječ o

25 Usp. Divković (n 5) 485 (ignis), 583 (innocens); Alfred Ernout i Antoine Meillet, Dictionnaire étymologique de la lingue latine (Klincksieck 2001) 307-308 (ignis), 440 (noceo, 2.).

26 Treba dodati, radi cjelovitosti pristupa, da i neovisno o tome, i da požar nije proizašao iz držane vatre već je došao izvan imanja, pitanje o krivnji ostaje isto. Glede čitanja prema Florentini i problemima koje ono povlači usp. Mayer-Maly (n 1) 195; JAC Thomas, 'Digest 19.2.9.3' (1962) 79 SZ RA 334 i sl.; Miquel (n 10) 170 i sl.; Frier (n 9) 246 i sl.; Molnár (n 10) 621 i sl.

27 Komentar uz B. 20, 1, 9, 3, Stephanus, ali i prateći Cyrillus, vidi u GE Heimbach i CGE Heimbach, Basilicorum libri LX, vol. II (Lipsiae 1840) 337. Za autora vidi više u HJ Scheltema, L'enseignement de droit des antécesseurs, (Brill 1970) 24 i sl.

28 Uz djela u bilj. 26 vidi i CF von Glück, Ausführliche Erläuterung der Pandecten nach Hellfeld: ein Commentar (Erlangen 1815) 485; Franz Haymann, 'Textkritische Studien zum römischen Obligationenrecht' (1919) 40 SZ RA 238, bilj. 3.

29 Sam termin praedium prema du Plessisu bio bi bliži pojmu fundus, u značenju zemljišta sa zgradama (du Plessis, op. cit. u bilj. 4, str. 146 i sl.) te bi u skladu s time bila vjerojatnija šteta na zgradama, nego na usjevima, iako trebamo istaknuti da se ni to ne može isključiti; primjerice, u poznatom Plinijevu pismu, Epist. IX, 37, uz zakup praedia navodi se samo ubiranje plodova.

30 Uz to, moguća zamjena termina u drugoj rečenici mogla bi se opravdati time da je i na još nekoliko mjesta ovog titula došlo do zamjene locator - conductor. Na tu zamjenu upućuje već i Mayer-Maly, a Miquel izravno navodi kao primjere zamjene D. 19, 2, 15, 9 te D. 19, 2, 30. Usp. Mayer-Maly (n 1) 196; Miquel (n 10) 161, bilj. 97.

31 Usp. Luzzatto (n 22) 220; Thomas (n 26) 334 i sl.; Molnár (n 10) 621 i sl. Ovdje možemo dodati da ni MacCormack ne upućuje na interpolaciju, no iznosi da u radu ima više spornih pitanja, od pogrešnog navoda da je riječ o Paulovu fragmentu do tumačenja da 
problemu odgovornosti za štetu zakupniku, odnosno razlici prema oslobođenju od zakupnine. Imajući na umu razliku između dva stupnja odgovornosti - quanti interest ili samo remissio koja se pojavljuje na više mjesta kod locatio conductio rei, ${ }^{32}$ može se protumačiti i Luzzattovu tezu da Ulpijan u tekstu upućuje na oslobođenje od eventualne obveze naknade štete zbog daljnje nemogućnosti frui. ${ }^{33}$ Naime, iako to Luzzato izričito ne navodi, argument bi mogao biti da zakupodavac ne odgovara za punu štetu, ali bi prema paraleli s D. 19, 2, 15, 3 (Ulpianus 32 ad edictum) zakupoprimac mogao tražiti smanjenje zakupnine zbog požara. Problem je pak to što u tekstu nema te diferencijacije te se samo navodi da zakupodavac ne snosi rizik štete (non praestabit periculum). Ako bi se ta šteta odnosila na fundus te bi zbog nje zakupoprimac bio spriječen u uživanju zemljišta, to bi u načelu bilo protivno rješenju o zakupodavčevom vim praestare iz D. 19, 2, 15, 2 kao temelju remissio. ${ }^{34}$ Navedenu činjenicu Molnár pak zaobilazi tumačenjem da je zakupoprimac požar uzrokovao krivnjom, iako, treba dodati, u tekstu nema nikakve naznake krivnje. ${ }^{35}$ Uostalom, ovo tumačenje bilo bi protivno i razlikovanju držanja obične i "bezopasne" vatre na koju Ulpijan upućuje u D. 19, 2, 11, 1, ${ }^{36}$ stoga ga se može bez daljnjeg zadržavanja zabaciti.

Thomas, koji je i jedini kao temu rada uzeo ovaj tekst, pružio je dva objašnjenja situacije iz prve rečenice zadržavajući non praestabit periculum locator, no priznajući sumnje u integralno stanje druge rečenice. ${ }^{37}$ Prema prvoj interpretaciji, koju smo već objasnili, fraza bi značila da će zakupodavac samo otpustiti preostali dug glede zakupnine, ali neće trebati nadoknaditi štetu koja bi nastala zbog nemogućnosti ispunjenja ugovora do kraja, dok bi prema drugoj, koju je sam iznio i detaljnije objasnio, ona odražavala stav da u slučaju uglavka kojim zakupoprimac ne preuzima odgovornost za slučaj na stvarima zakupodavca, to ne bi istodobno značilo da će tada za slučajno nastalu štetu na stvarima zakupoprimca odgovarati zakupodavac. ${ }^{38}$ Naime, prema Thomasovu mišljenju naglasak u trećem paragrafu na stvarima je zakupoprimca koje su uništene u požaru, a ne na stvarima zakupodavca zbog kojih zakupoprimac ne bi mogao koristiti imanje i obrađivati zemljište i na koje bi se odnosila obveza smanjenja zakupnine koju smatra predviđenom tek u 4. paragrafu. ${ }^{39}$ Pravno-tehnički, može se reći da bi rješenje u vezi s

bi se u tekstu periculum odnosio i na culpa u drugoj rečenici, što smatramo da se može vrlo teško zaključiti. Usp. MacCormack (n 12) 145.

32 Uz druge, to je vidljivo u D. 19, 2, 19, 1, D. 19, 2, 30 pr. te D. 19, 2, 33, a možda najzornije razliku objašnjava Ulpijan u D. 19, 2, 15, 7. Usp. Emilio Betti, 'Zum Problem der Gefahrtragung bei zweiseitig verpflichtenden Verträgen' (1965) 82 SZ RA 20.

33 Luzzatov zaključak se može izvući iz sljedećih riječi: "Egli, cioè, dichiara, nei confronti del colono, che, se un incendio si verificasse, le conseguenze di questo non gli nuoceranno punto, nel senso che il locatore sarà esente dall'obbligo di assicurare al conduttore la continuazione del frui sino alla fine del contratto." Usp. Luzzatto (n 22) 220.

Usp. Molnár (n 10) 621 i sl.

Uz D. 19, 2, 11, 1 Molnár navodi "Die Bedeutung des Textes wird durch die nachklassische Überarbeitung in gewissen Umfang gemindert", no ne spominje u vezi s tim ni općenito razlikovanje bezopasnog i običnog plamena, već se samo u tekstu poziva na Mayer-Malya i njegovu konstataciju o odgovornosti zakupoprimca za višu silu u svakom slučaju kada je postupio protivno uglavku, no koji u vezi sa svim ovim tekstovima zastupa drukčiji stav. Ponajprije to vrijedi za D. 19, 2, 9, 3 glede kojega je MayerMaly iznio tezu o znatnijem zahvatu u smisao teksta kompilatora, a Molnár je to odbio ustvrdivši da je tekst kraćen, no da je bit ostala ista. Usp. Mayer-Maly, (n 1) str. 196; Molnár (n 10) 622, 633.

38 Thomas navedeno objašnjava sljedećim riječima: "The fact that locator in effect says to the conductor, "You will be liable if you do (or do not do) such-and-such", does not in itself automatically infer, "I will be liable in all other circumstances"." Ibid 338.

39 Možemo citirati objašnjenje u kojem je najočitiji način racionalizacije mjesta i uloge ovog dijela teksta: "Then, taking 9.2, 9.3 and 9.4 together, there is - if locator be accepted as correct in 9.3 - a link between the three sentences from the tenant's standpoint. 
prvom rečenicom bilo odgovarajuće u toj mjeri da lokator ne odgovara za štetu koja bi slučajno nastala na stvarima zakupoprimca. Sumnjamo, međutim, da bi navedeno pitanje uopće bilo postavljeno, odnosno da bi Ulpijanu, koji sam ili preuzimajući Servijevu logiku jasno razdvaja između štete na sjemenu i štete zbog nemogućnosti frui praestare u D. 19, 2, 15, 2, bilo sporno i potrebno obrazložiti da zakupodavac nije odgovoran za slučajnu štetu na stvarima zakupoprimca. Štoviše, možemo još jedanput spomenuti pitanje, a u vezi s drugom rečenicom, na koji način bi zakupodavac bio kriv za razvoj požara od vatre koju su držali koloni, odnosno kako povezati problemsku situaciju i taj drugi odgovor. Iz samog teksta ne proizlazi ništa što bi indiciralo neku vezu. Doduše, na temelju drugih fragmenata moguće je zamisliti da bi požar primjerice nastao kao rezultat djelovanja treće osobe koje je zakupodavac mogao spriječiti te bi tada bio kriv, no čini nam se da bi navedeno išlo predaleko od biti pravnog problema i ignem innocentem. Thomas doduše priznaje da je ta druga rečenica u određenoj mjeri prerađena, ali ako se prihvati izvornost prvog dijela, vjerujemo da bi se onda prema izričaju trebala s time uvezati i druga rečenica koja bi se u osnovi referirala na učinke uglavka kao temelja paragrafa, a ne je odbaciti kao sumnjivu.

S druge strane, Mayer-Maly, Miquel i Frier prihvaćaju varijantu izričaja prema Vulgati uz naznaku šireg ili užeg opsega interpolacija. ${ }^{40}$ Mayer-Maly je tako uputio na zamjenu locator s conductor te je brisao drugu rečenicu, dok je ideju samog paragrafa protumačio u odnosu prema prethodnom, D. 19, 2, 9, 2, u kojemu je zakupoprimac uglavkom preuzeo odgovornost za višu silu, što u ovome ne bi bio slučaj. ${ }^{41}$ Naime, uglavkom kojim mu je dopušteno držanje bezopasne vatre, za razliku od uglavka kojim mu je općenito zabranjeno paliti bilo kakvu vatru, zakupoprimac bi isključivao odgovornost za požar kao casus fortuitus. Miquel, uz stavljanje naglaska na postojanje obje varijante još od Justinijanova doba te s uputom na sholije, općenito daje prednost čitanju iz Vulgate, ${ }^{42}$ kao i Frier čija se osnovna argumentacija temelji na općim razlozima - lako moguća zamjena pojmova, u navedenom nizu fragmenata raspravlja se o odgovornosti zakupoprimca a ne zakupodavca, suprotno tumačenje u tekstualnoj tradiciji Bazilika te sadržaj D. 19, 1, 11, 1. ${ }^{43}$ Ključni element Frierova izlaganja, u smislu koji u bitnome odgovara ranijem obrazloženju Mayer-Malya, ${ }^{44}$ jest shvaćanje uloge teksta kao pokazatelja posebne, objektivne odgovornosti zakupoprimca za štetu zbog kršenja obveze iz uglavka, različite od "culpa liability” kao redovnog kriterija prosudbe okolnosti u kojima će zakupoprimac biti obvezan nadoknaditi štetu. ${ }^{45}$ Prema tome, ako bi zakupoprimac palio "opasnu vatru”, glede čega se primjerice upućuje na razliku paljenja vatre na ognjištu kao sigurne i one na polju (strnište) kao opasne, odgovarao bi ako bi požar nastao i bez njegove krivnje, no ako bi se slučajno razvio požar od sigurne vatre, npr. na ognjištu ili u peći, tada ne bi bio odgovoran. ${ }^{46}$

9.2 says, in effect, "If you accept liability for casus, you will have to pay"; 9.3, "If you accept other abnormal liability but less than casus, that does not mean that locator will be liable to you in the event of casus"; and 9.4, "But he will have to release you from further rent liability"." Ibid.

Vidi Mayer-Maly (n 1) 195; Miquel (n 10) 172 i sl.; Frier (n 9) 247.

Usp. Mayer-Maly (n 1) 195.

Usp. Miquel (n 10) 172 i sl.

Usp. Frier (n 9) 247.

Usp. Mayer-Maly (n 1) 195.

Usp. Frier (n 9) 248 - 249.

Ibid str. 248. Iako se u ovom ni kasnije obrađenim tekstovima ne spominje gdje i kako je vatra paljena, u vezi s Frierovom opaskom o različitim mjestima i uvjetima paljenja vatre možemo uputiti na Birksovo izlaganje u vezi s različitim oblicima 
Samo ako je požar buknuo od sigurne vatre zbog njegove krivnje, u tom slučaju bi postojala njegova odgovornost.

Doista, mišljenje potonje skupine autora i vulgatno čitanje smatramo da više odgovara i kontekstu samog fragmenta i šire titula, kao i odnosima odgovornosti koji bi izvirali iz slučaja štete uzrokovane požarom. Uzimajući u obzir okvire fragmenta i rasprave o štetama na imanju, pri čemu smatramo da je ta šteta implicirana i u ovom paragrafu prema postavljenom uglavku, čini nam se nelogičnim da bi Ulpijan koncipirao rješenje fragmenta uvodeći potpuni obrat odgovorom da zakupodavac nije odgovaran za štetu na (vlastitoj) stvari, posebno glede posljednje rečenice u kojoj se upućuje na njegovu krivnju. U vezi s istom, moguće bi bilo prihvatiti i stav Mayer-Malya prema kojem bi druga rečenica bila umetnuta, ${ }^{47}$ što bismo mogli objasniti namjerom pojašnjenja riječi locator koja se ovdje neočekivano pojavljuje, možebitno kao rezultat određene pogreške u prijepisu jer je ipak riječ samo o jednom $i$, odnosno problemu u transmisiji teksta koji je bio na raspolaganju kompilatorima. Ako bi se pak prihvatilo da je i druga rečenica sastavni dio izvornog teksta, iako u izmijenjenom obliku s krivnjom zakupoprimca, ona bi tada imala i veću težinu postavljajući u odnos suprotnosti periculum prema culpa. Pritom je periculum, glede kojega postoji problem višestruke uporabe u značenju snošenja rizika kustodije i/ili više sile, ${ }^{48}$ preciziran ovdje u smislu potonje, konkretnije navodeći slučaj kao uzrok nastanka požara. Riječima fortuitus casus incendii causam intulerit, u situaciji u kojoj je kolonima uglavkom bilo dopušteno držati vatru, izravno je otklonjena njihova odgovornost a koja bi postojala ili da im nije bilo općenito dopušteno držati vatru ili da su je skrivili. Stoga i rizik štete na dobrima i same nemogućnosti obrade zemljišta (frui) do kraja dogovorenog roka ne bi bili na zakupoprimcu kao u prethodnom paragrafu (D. 19, 2, 9, 2) kada je on preuzeo na sebe odgovornost, praestare, za višu silu. Također, činjenica da je uglavak dogovoren u korist lokatora, u smislu zaštite njegovih interesa i njegova imanja od toga da zakupoprimci i njihovi robovi ne pale vatre bez kontrole i zaštite, izvan predviđenih mjesta jer bi tada odgovarali i ako se požar proširi slučajno, prije nas upućuje na to da bi njegovo tumačenje, na način kako su početak paragrafa i situacija s požarom postavljeni, išlo u korist zakupoprimca, a ne da bi njime bio ekskulpiran zakupodavac.

Glede suprotne teze u korist izvornosti teksta, kao što se susreće kod Luzzata, pak, vjerujemo da oblici argumentacije u ostalim izvorima u kojima se razlikuje zakupodavčeva odgovornost za štetu zbog krivnje od dužnosti remissio kod više sile, poput D. 19, 2, 19, 1 (Ulpianus 32 ad edictum) ${ }^{49}$ daju jasnu naznaku da ovdje ne bi bila riječ o tome da je Ulpijan samo htio reći da zakupodavac ne treba nadoknaditi svu štetu zakupoprimcu, već samo otpustiti ostatak duga. Smatramo da u navedenom smjeru upućuju i drugi tekstovi u vezi držanja vatre i opasnosti od požara kod zakupa koje ćemo analizirati u nastavku.

ognjišta i peći te terminološkim varijacijama u povodu analize D. 9, 2, 27, 10 (Ulpianus 18 ad edictum). Usp. Peter Birks, Cooking the Meat: Aquilian Liability for Hearths and Ovens (1985) 20(2) Irish Jurist 356 i sl. 


\section{UGLAVCI O PROŠIRENJU ILI OGRANIČENJU ODGOVORNOSTI ZAKUPOPRIMCA ZBOG OPASNOSTI OD POŽARA}

U najužoj vezi s obzirom na vrlo sličan uglavak, ali i spominjanje ignem innocentem, drugi je tekst također preuzet iz 32. knjige Ulpijanova komentara pretorskog edikta, višekratno spomenuti D. 19, 2, 11, 1 (Ulpianus 32 ad edictum). Riječ je o paragrafu u kojem je raspravljen slučaj s uglavkom prema kojemu zakupoprimac odgovara za svaki požar ako je palio vatru suprotno zabrani, no iako ni tu nije točno navedeno na kojim stvarima je nastala šteta, prema uvodnom paragrafu može se pretpostaviti da bi bila riječ o šteti na stvarima zakupodavca:

D. 19, 2, 11, 1 (Ulpianus 32 ad edictum) Si hoc in locatione convenit "ignem ne habeto" et habuit, tenebitur etiam si fortuitus casus admisit incendium,,$^{50}$ quia non debuit ignem habere. Aliud est enim ignem innocentem habere: permittit enim habere, sed innoxium, ignem. ${ }^{51}$

U skladu s lex locationis koji predviđa da zakupoprimac ne smije paliti vatru, no držao ju je te se ona slučajem razvila u požar, zakupoprimac će odgovarati za štetu. Naglašeno je da je požar nastao slučajem, također, etiam, s obzirom na opće pravilo da bi svakako odgovarao da je do toga došlo njegovom krivnjom. Od toga je razdvojena situacija (Aliud est enim) u kojoj je postojala odredba o neopasnom plamenu, tj. kada je bilo dopušteno držati bezopasnu vatru, međutim, u literaturi su izražene sumnje da je riječ o dodatku ili bar u određenoj mjeri promijenjenom tekstu kojim se u prvom redu nastojao pojasniti odnos prve rečenice prema D. 19, 2, 9, 3, odnosno obrazložiti različita rješenja u dvama fragmentima. ${ }^{52}$ Frier pritom smatra da su oba teksta bila dio iste rasprave, no da su pri pripremi Digesta razdvojena. ${ }^{53}$ Možemo se složiti glede povezanosti u smislu da bi tekstovi bili dio istog odjeljka odgovarajuće knjige koja se odnosila na situacije u kojima se mogla podignuti actio locati te da među fragmentima postoji u određenoj mjeri kontinuitet, koji je u Digestama narušen samo kratkim ubacivanjem D. 19, 2, 10 (Iulianus libro ad ferocem) kao dopune D. 19, 2, 9, 6. Dvojbu jedino uzrokuje uvod ili principium D. 19, 2, 9, 11 u kojem je predmet izlaganja odgovornost za štetu koju bi uzrokovale osobe koje su bile podčinjene zakupoprimcu, a koji bi mogao implicirati, iako to nije nužno s obzirom na drugi i treći paragraf, da bi se fortuitus casus u ovom prvom paragrafu odnosio na djelovanje članova domaćinstva. U tom bi smislu razlika između dva bila u tome da je u D. 19, 2, 9 bila raspravljena situacija odgovornosti zakupoprimca osobno, dok je u D. 19, 2, 11 polazišni problem odgovornosti za robove i druge osobe pod vlašću ili kontrolom.

50 U skladu s njegovim općim stavom Luzzatto i ovdje fortuitus casus, odnosno dio od etiam do incendium smatra interpoliranim. Usp. Luzzatto (n 22) 219; contra vidi Behrens (n 22) 58.

51 D. 19, 2, 11, 1: "Ako se u ugovoru o zakupu dogovori "da se ne drži vatra (plamen)" i bude držana, bit će odgovoran i ako požar nastane slučajem jer nije bilo dopušteno držati vatru. Drugo je naime (ako se dogovori) držati "bezopasnu vatru”; tada je dopušteno držati vatru, ali bezopasnu." Usp. Lenel (n 23) vol. II, 638; Mayer-Maly (n 1) 195; Miquel (n 10) 172 i sl.; Molnár (n10) 633 i sl.

52 Takav stav jasnije iznose Mayer-Maly i Thomas, prvi ukazujući na razliku u licima i formi rečenica, potonji upućujući da bi bila riječ o "familiar type of explicative insertion - doubtless occasioned precisely by the proximity of 9.3..." (str. 337). Frier također drugu rečenicu stavlja pod sumnju iako nešto blažim riječima: "At least this first sentence seems classical." (str. 256). S druge strane Miquel i du Plessis ne spominju moguće izmjene. Usp. Mayer-Maly (n 1) 195; Miquel (n 10) 172; Thomas (n 26) 337; Frier (n 9) 246; du Plessis (n 3) 277. Ranije stavove o interpolacijama u tekstu vidi u Schulz (n 22) 33 i sl.; Haymann (n 28 ) 252 i sl. 
Ključno je i u D. 19, 2, 9, 3 i D. 19, 2, 11,1 da bi zakupoprimac potencijalno odgovarao za štetu koja je rezultat požara koji se razvio slučajem ako je postupao suprotno uglavku, što u D. 19, 2, 9, 3 nije učinio, odnosno nema naznaka da je držao "opasnu vatru”. Za razliku od općenite odgovornosti za namjerno ili nepažnjom uzrokovanu štetu i onu koja je nastala vlastitim ponašanjem i ponašanjem sebi podčinjenih osoba ili gostiju na što upućuje D. 19, 2, 11 pr., ${ }^{54}$ činjenica da je u D. 19, 2, 11, 1 zakupoprimac svjesno postupao protivno dogovorenome povlači njegovu odgovornost i za višu silu. ${ }^{55}$ Možemo dodati da iako se izričito ne kaže kako je i zašto postupao suprotno uglavku, iz samog navoda habuit, da je držao vatru, proizlazi da bi to bilo svjesno. ${ }^{56}$

Isto se može ustvrditi i glede D. 19, 2, 11, 4 u kojem je raspravljen drugi lex locationis, o zabrani spremanja sijena u kući, sa sličnim posljedicama, a na koji je pridodan i Hermogenijanov tekst sačuvan u D. 19, 2, 12:

D. 19, 2, 11, 4 (Ulpianus 32 ad edictum) Inter conductorem et locatorem convenerat, ne in villa urbana faenum componeretur: composuit: deinde servus igne illato succendit. Ait Labeo teneri conductorem ex locato, quia ipse causam praebuit inferendo contra conductionem. ${ }^{57}$

D. 19, 2, 12 (Hermogenianus secundo iuris epitomarum) Sed etsi quilibet extraneus ignem iniecerit, damni locati iudicio habebitur ratio. ${ }^{58}$

U uglavku koji je obrađen u četvrtom paragrafu nije konkretno spomenuto držanje vatre, no riječ je o bliskoj zabrani držanja sijena u rezidencijalnom dijelu seoskog gospodarstva ${ }^{59}$ što se ponajprije može objasniti izbjegavanjem pojave požara zbog lake zapaljivosti sijena. ${ }^{60}$ Za razliku od općenito postavljenog casus fortuitus u prvom paragrafu, ovdje se konkretnije navodi da je uzročnik zakupoprimčev rob koji je unio vatru, iako se i pritom može zaključiti da je požar nastao slučajem, a ne namjerno. Međutim, gospodar odgovara i za tako nastao požar. Ulpijan se pritom poziva na Labeonovo mišljenje, iako su u literaturi izražene sumnje glede opravdanja potječe li ono od Labeona ili je riječ o naknadnoj intervenciji. ${ }^{61}$

54 Vidi bilj. 62

55 Radi paralele, primjerice, može se navesti u vezi s krivnjom kod actio legis Aquiliae Paulov tekst D. 9, 2, 30 , 3 (Paulus 22 ad edictum) prema kojem je onaj koji je palio strnište odgovoran i za slučaj ako je to činio na vjetrovit dan ili je držao vatru duže od predviđenoga. Glede teksta usp. primjerice Arangio-Ruiz (n 12) 232; Geoffrey MacCormack, 'Aquilian Culpa' u Alan Watson (ed), Daube noster: Essays in Legal History for David Daube, (Scottish Academic Press 1974) 207 i sl.

56 Cannata smatra da se krivnja zakupoprimca očituje upravo u ponašanju protivno uglavku. S druge strane, Fercia ističe da se u relevantnim tekstovima ne spominje culpa te bi ovdje bila riječ o raspodjeli rizika, a ne o problemu subjektivne ili objektivne odgovornosti. Usp. Cannata (n 12) 64 i sl.; Fercia (n 9) 86 i sl.

57 D. 19, 2, 11, 4: "Dogovoreno je između zakupoprimca i zakupodavca da u vili neće biti sakupljano sijeno, no sakupljeno je. Poslije ga je rob unesenom vatrom zapalio. Labeon kaže da je zakupoprimac odgovaran s actio locati jer je sam omogućio uzrok unoseći (sijeno) protivno ugovoru." Usp. Lenel (n 23) vol. II, 638.

58 D. 19, 2, 12: “Ali također i ako bi neki stranac unio vatru, postojat će osnova za podizanje actio locati za naknadu štete." Usp. Lenel (n 23) vol. I, 270.

59 Glede definicije villa urbana kao dijela za stanovanje seoskog imanja oslonac je na Bergera i Purcella, na koje upućuje i du Plessis Usp. Adolf Berger, Encyclopedic Dictionary of Roman Law (The American Philosophical Society 1953 [1980]) 765; Nicholas Purcell, 'The Roman villa and the landscape od production' u Tim J Cornell i Kathryn Lomas (eds), Urban Society in Roman Italy (Routledge 1996) 157 i sl; du Plessis (n 4) 148.

$60 \quad$ Usp. Mayer-Maly (n 1) 197.

61 Naime, Mayer-Maly je pozivajući se na stariju doktrinu uputio na interpolaciju dijela od quia do kraja paragrafa, u prvom redu zbog conductionem umjesto očekivanog conventionem. Thomas je također prihvatio navedeni argument u prilog tome da je riječ o promijenjenom tekstu koji bi uključivao odgovornost prema lex Aquilia. Konačno, i Frier upućuje da bi bila riječ o postklasičnoj izmjeni, dok du Plessis samo prenosi mišljenja prethodnika. S druge strane možemo spomenuti da Haymann drži da je tekst 
Kompilatori su na Ulpijanov tekst dodali odmah i Hermogenijanovo rješenje o odgovornosti i u slučaju ako bi bilo tko treći unio vatru, ukazujući na taj način da bi sama činjenica da je sijeno držano suprotno dogovoru povlačila odgovornost za naknadu štete bez obzira na to je li zakupoprimac bio kriv ili ne. Navedeno je bilo potrebno jer je u uvodu istog fragmenta, ${ }^{62}$ u kojem Ulpijan opravdava svoje rješenje pozivom na ranije Pomponijevo mišljenje, istaknuto da zakupoprimac odgovara za štetu koja je nastala skrivljenim ponašanjem (culpa) slobodnih osoba koje je uveo, u smislu da je bio nemaran jer im je dopustio da uđu na imanje ili u kuću. ${ }^{63}$ U uvodu je pritom izričito navedeno etsi nihil convenit (iako ništa nije posebno ugovoreno), prema čemu bi slijedila odgovornost samo za krivnju, no kao što se u slučaju povrede obveze iz lex locationis u D. 19, 2, 11, 1 i 4 odgovara i za slučajno nastalu štetu vlastitim ili djelovanjem robova, tako bi prema D. 19, 2, 12 zakupoprimac paralelno odgovarao i za treće, bez obzira na vlastitu ili njihovu krivnju.

Thomas je raspravljajući o odnosu actio locati/conducti i actio legis Aquiliae u vezi sa D. 19, 2, 11, 4 istaknuo da ni Ulpijan ni Labeon ne spominju noxae datio, koja bi prema svemu sudeći trebala postojati na temelju sličnosti prema D. 19, 2, 11 pr., upućujući da je razlog bila Labeonova želja naglasiti ovdje ugovornu odgovornost zakupoprimca za cjelokupnu štetu te stoga nije povučeno posebno pitanje noxae.$^{64}$ Smatramo da je tu potrebna određena dopuna, $u$ smislu da je u navedenom slučaju, upravo uzimajući u obzir D. 19, 2, 11 pr., a u određenoj mjeri kao referencu i tekst D. 9, 2, 27, 9 (Ulpianus 18 ad edictum) ${ }^{65}$ koji se također odnosi na štetu

"echt". Cardilli se također izjašnjava da tekst nije mijenjan, posebno glede conductionem, a može se reći da njegova razmišljanja glede teksta slijedi i Fercia. S obzirom na logičnost nastavka te određenu paralelu s načinom argumentacije u D. 19, 2, 57 (Iavolenus 9 ex posterioribus Labeonis) skloniji smo ustvrditi da je riječ o Labeonovu tekstu koji je pretrpio određeno kraćenje, no da je u bitnome ostala izvorna jezgra. Usp. Haymann (n 28) 238; HH Pflüger, 'Zur Lehre von der Haftung des Schuldners nach römischem Recht' (1947) 65 SZ RA 195; Mayer-Maly (n 1) 197 (posebno vidi bilj. 51 i 52); Thomas (n 26) 337; Frier (n 9) 249; Cardilli (n 10) 367; Fercia (n 9) 85; du Plessis (n 4) 149.

62 D. 19, 2, 11 pr. (Ulpianus 32 ad edictum) Videamus, an et servorum culpam et quoscumque induxerit praestare conductor debeat? Et quatenus praestat, utrum ut servos noxae dedat an vero suo nomine teneatur? Et adversus eos quos induxerit utrum praestabit tantum actiones an quasi ob propriam culpam tenebitur? Mihi ita placet, ut culpam etiam eorum quos induxit praestet suo nomine, etsi nihil convenit, si tamen culpam in inducendis admittit, quod tales habuerit vel suos vel hospites: et ita Pomponius libro sexagesimo tertio ad edictum probat. (Vidimo: Mora li zakupoprimac odgovarati i za krivnju robova i bilo kojih drugih osoba koje bi uveo? I ako odgovara, je li dužan samo noksalno predati robove ili odgovara u svoje ime? I s obzirom na one koje bi uveo (treće osobe), je li dužan samo prenijeti tužbe protiv njih ili odgovara kao da je sam kriv? Moje mišljenje je da odgovara za nepažnju i onih koje je uveo, i ako ništa nije posebno ugovoreno, te se prihvaća krivnja zbog toga što ih je takve uveo (kod sebe), ili svoje ili goste. To potvrđuje i Pomponije u 63. knjizi komentara pretorskog edikta.)

63 Usp. du Plessis (n 3) 278. Također usp. Knütel, R (n 16) 401 i sl.

64 Vidi JAC Thomas, 'Actiones ex locato/conducto and Aquilian Liability' (1978) 20 Acta Juridica 129. Također glede teksta usp. Schulz (n 22) 33 i sl.

65 D. 9, 2, 27, 9 (Ulpianus 18 ad edictum) Si fornicarius servus coloni ad fornacem obdormisset et villa fuerit exusta, Neratius scribit ex locato conventum praestare debere, si neglegens in eligendis ministeriis fuit: ceterum si alius ignem subiecerit fornaci, alius neglegenter custodierit, an tenebitur qui subiecerit? Nam qui custodit, nihil fecit, qui recte ignem subiecit, non peccavit: quid ergo est? Puto utilem competere actionem tam in eum qui ad fornacem obdormivit quam in eum qui neglegenter custodit, nec quisquam dixerit in eo qui obdormivit rem eum humanam et naturalem passum, cum deberet vel ignem extinguere vel ita munire, ne evagetur. (Ako je zakupnikov rob zadužen za čuvanje vatre (odnosno peći, ognjišta ili ložišta) zaspao uz vatru i kuća je izgorjela, Neracije tako piše da će zakupnik morati odgovarati iz ugovora o zakupu ako je bio nemaran pri izboru pomoćnika. Drugo je pitanje ako je jedan potpalio vatru na ognjištu, a drugi je nepažljivo čuvao, je li odgovaran onaj koji ju je potpalio. Naime, onaj koji ju čuvao nije ništa učinio (u smislu djelovanja zahtijevanog prema actio legis Aquiliae, op. a.), dok ju je drugi ispravno potpalio te nije učinio ništa pogrešno. Što je onda? Smatram da se može podignuti actio utilis kako prema onome koji je zaspao uz vatru, tako i prema onome koji je nepažljivo čuvao, tako da ne bi nitko rekao glede onoga što je zaspao da mu se dogodilo ono što je ljudski i prirodno jer je morao ili ugasiti vatru ili je osigurati da se ne proširi.)

Uz ovaj tekst treba istaknuti da cijeli dio fragmenta od D. 9, 2, 27, 7 do 12 obuhvaća slučajeve odgovornosti zbog paleža, odnosno štete nastale vatrom, te je s određenim razlikama i dodacima sadržan u Collatio legum Mosaicarum et Romanarum unutar titula De incendariis, Coll. 12, 7, pri čemu D. 9, 2, 27, 9 odgovara Coll. 12, 7, 7. 
nastalu od požara i upućuje na alternativnu primjenu actio locati sa actio legis Aquiliae te bi s te strane pripadao predmetu rasprave $\mathrm{u}$ radu ${ }^{66}$ ključan problem krivnje samih robova, odnosno njegov izostanak ili preciznije irelevantnost u D. 19, 2, 11, $4 .{ }^{67}$ S obzirom na to da u D. 19, 2, 11, 4 uopće nije bilo potrebno raspravljati o sekundarnoj odgovornosti gospodara za akte robova, ni kontraktnoj ni deliktnoj, ${ }^{68}$ i to zbog zakupoprimčeve objektivne odgovornosti zbog kršenja obveze iz lex locationis, smatramo da je upravo navedeno bilo razlogom ograničenja argumenta u tekstu.

Uz sam tekst istaknuli bismo i riječ causa koja se javlja i ovdje, u smislu da je zakupoprimčevo ponašanje omogućilo nastanak požara jer je postavio jedan od nužnih elementa za njegov nastanak, kao i u D. 19, 2, 9, 3, no sa suprotnim predznakom, u smislu da je u potonjemu vatra kao jedan od elemenata bila dopuštena dok je njezino prerastanje u požar (causa) uzrokovano slučajem, bez sudjelovanja zakupoprimca. Da je bilo kakva vatra bila nedopuštena, kao što je slučaj u D. 19, 2, 11, 1, očito bi došlo do odgovornosti, bez obzira na fortuitus casus. Također, u sva tri teksta može se uočiti funkcija fortuitus casus kao općenitog ${ }^{69}$ načina objašnjenja nastanka požara, incendium, iz vatre, ignis. Iako se fortuitus casus često uzima kao sinonim s vis maio$r,{ }^{70}$ smatramo da je kod požara, a s obzirom na mogućnost utjecaja ljudskog elementa, vidljiva određena razlika. Dok bi incendium kao pojava općenito bio obuhvaćen primjeričnim nabrajanjem oblika vis maior, uz brodolom, potres, oluju i slične, ${ }^{71} \mathrm{u}$ ovdje analiziranim slučajevima čini nam se važnijom oznaka načina njegova nastanka koja je imala bitne posljedice u vezi s odgovornosti stranaka. ${ }^{72}$ Pritom bismo posebno istaknuli i činjenicu da su već ranije, moguće već u doba Zakonika 12 ploča prema onome što prenosi Gaj u D. 47, 9, 9 (Gaius 4 ad legem duodecim tabularum), Rimljani razlikovali situacije, a u vezi s time i oblik odgovornosti, kada bi se iz nečije vatre namjerno ili slučajno razvio veliki požar te uzrokovao štetu susjedima. ${ }^{73} \mathrm{U}$ smislu

Glede terminologije u vezi s fornax, češće u smislu peći, u kojem smislu i furnus, uz focus kao precizniju oznaku ognjišta, ložišta, uz uputu supra u bilj. 46 na Birksa, vidi Divković (n 5) 424, 427, 441; Ernout i Meillet (n 25) 243, 248.

Naime, kao što je vidljivo iz teksta D. 9, 2, 27, 9 prvo se navodi alternativna mogućnost podizanja actio locati ili actio legis Aquiliae, uz pretpostavku krivnje kolona, a zatim se problematizira krivnja podčinjenih osoba kao temelj odgovornosti prema actio legis Aquliae, odnosno konkretnije actio utilis (Digesta) ili ad exemplum Aquiliae (prema Collatio). S uputom na daljnju literaturu vidi Frier, op. cit. u bilj. 9, str. 256 i sl.

67 Uz to se možemo osvrnuti i na u uvodu spomenuti tekst, D. 9, 2, 27, 11, odnosno širu verziju sačuvanu u Coll. 12, 7, 9, u kojoj se prvo navodi Sabinovo mišljenje da u slučaju kada su zakupoprimčevi robovi zapalili vilu zakupoprimac može odgovarati samo prema actio legis Aquiliae, dok je u Digestama prenesen samo dio u kojem se Ulpijan oslonio na Prokulovo mišljenje i dopuštenu konkurenciju actio locati ili actio legis Aquiliae, pri čemu se, međutim, raspravlja samo o krivnji zakupoprimca. Opširnije o tekstu, s uputom na daljnju literaturu, vidi u Frier (n 9) 261 i sl.; Fercia (n 9) 72 i sl., 107 i sl.

68 Uzimajući u obzir složenost problema te druge povezane tekstove, ovdje nije moguće šire ulaziti u raščlambu pitanja noxae datio u kontekstu locatio conductio, već se može inicijalno uputiti na prethodno navedene komentare uz D. 19, 2, 11 pr.

69 U vezi s požarom može se primjerice vidjeti u već spomenutom D. 9, 2, 30, 3 da je razbuktavanje vatre objašnjeno konkretno sa subita vis venti, dok bi fortuitus casus bio opći pojam kojim bi neodređeno bile pokrivene sve one okolnosti koje su dovodile do požara bez krivnje, a koje su vjerojatno češće bile i nepoznate strankama obveznog odnosa.

70 Glede istovjetnog ili različitog opsega, odnosno jednakosti i razlika, ne ulazeći u rasprave o interpolacijama, vidi primjerice Behrens (n 22) 57 i sl.; Mayer-Maly (n 6) 63 i sl.

71 Vidi primjerice Mayer-Maly (n 6) 64 i sl.

72 Na fortuitum incendium, ili slučajno nastalu vatru (accidental fire) u širem kontekstu deliktne odgovornosti, kao "old concept of fire as a dangerously self-willed being" koji je prevladavao do kraja klasičnog prava, pri čemu fortuitus "suggests something ungovernable, unforeseeable" upozorava Daube. Vidi David Daube, 'Nocere and noxa' (1939) 7 Cambridge Law Journal 23 i sl. (stranice prema: David Daube Collected studies in Roman Law, I., (Vittorio Klostermann, 1991) 79)

73 U vezi s pitanjem izvorne diferencijacije namjernog i nenamjernog uzrokovanja štete zbog širenja požara prema Zakoniku 12 ploča u vezi s D. 47, 9, 9 te širenja primjene trećeg poglavlja lex Aquilia na "inanimate objects" i štetu od požara usp. David Daube, On the Third Chapter of the lex Aquilia (1936) 52 Law Quarterly Review 253 i sl.; Geoffrey MacCormack, 'Fault and 
isticanja načina nastanka požara može se ustvrditi da bi na dobrom tragu bile i Nörrova opaska o potrebi dubljeg istraživanja odnosa casus fortuitus i krivnje ${ }^{74}$ te Ernstova naznaka veze tog odnosa s njegovim Leistungsfpflichtbezogene shvaćanjem više sile kao razloga isključenja odgovornosti zbog odsutnosti krivnje. ${ }^{75}$ Naime, prema Ernstovom shvaćanju, u osnovnim crtama, ${ }^{76}$ u razvoju sadržaja pojma više sile mogu se razlikovati dvije etape - prva u kojoj je šteta više sile teretila vlasnika stvari te je s te strane i naziva Sachbezogene, a koja se samo posredno odražavala na obvezni odnos, pri čemu je polazišni argument Servijevo objašnjenje iz D. 19, 2, 15, 2 o zakupodavčevoj nemogućnosti frui praestare uz potvrdu nizom drugih izvora, dok je tek u drugoj fazi izravno postala obveznopravno relevantna (Leistungsfpflichtbezogene) kao razlog isključenja odgovornosti dužnika. Glede ove druge etape Ernst se oslanja na slučajeve u kojima je dužnik odgovarao i za vis maior ako bi se sam doveo u situaciju u kojoj je šteta nastala zbog djelovanja više sile. Također, u vezi s potonjim on se u prvom redu poziva na D. 2, 11, 2 , 3-8 (Ulpianus 74 ad edictum) te D. 13, 6, 5, 4 (Ulpianus 28 ad edictum), dok bismo sami ocijenili da bi to drugo shvaćanje možda najopipljivije bilo u vezi sa situacijama koje su navedene kao primjer prijelaza, a u kojima se fortuitus casus i vis maior (kao pojava) nalaze jedno uz drugo (Ernst iznosi šire shvaćanje koje obuhvaća i slučajeve u kojima fortuitus casus ili casus maior zamjenjuju vis maior), upućujući time da bi u razmatranje dolazila i skrivljenost ponašanja zbog kojeg bi došlo do nemogućnosti ispunjenja činidbe. ${ }^{77}$

Na ovom mjestu iznijeli bismo tek opasku u vezi s Ernstovom tezom da bi se funkcija fortuitus casus doista mogla tumačiti u smislu promjene koncepcije više sile kao oblika ograničenja ugovorne odgovornosti, no već i postojanje lex locationis čiju valjanost potvrđuje Julijan u D. 19, 2, 9, 2 s ciljem prebacivanja rizika na drugu stranu ukazivalo bi na višu silu kao Leistungsfpflichtbezogene, i to ranije od pretpostavljenoga. Uz to se mogu iznijeti i druge primjedbe, međutim, kako je riječ o dijelu rasprave šireg problema sadržaja i razvoja pojma više sile kojemu je posvećeno mnogo prostora u literaturi rimskog prava, a koji će biti zasebno analiziran, ovdje nećemo dublje ulaziti u to pitanje.

Causation in Early Roman Law: An Anthropological Perspective' (1981) 28 Revue internationale des droits de l'antiquité 117 i sl.; Zimmermann (n 8) 957 i sl.; MF Cursi, 'The Scope and Function of Civil Wrongs in Roman Society' u PJ du Plessis, Clifford Ando i Kaius Tuori (eds), The Oxford Handbook of Roman Law and Society (Oxford University Press 2016) 597.

74 Iz Nörrova komentara na Mayer-Malyev članak u okviru prikaza FS Steinwenter možemo pritom izdvojiti: "Möglicherweise liegt der Unterschied in der größeren Abstraktion im Begriffe des casus und seiner stärkeren Affinität zum Verschuldenssystem." Usp. Dieter Nörr, rec. 'Festschrift für Arthur Steinwenter zum 70. Geburtstag' Böhlau, Graz, 1958, (1959) 76 SZ RA 634.

75 U vezi s tvrdnjom navedenom u tekstu vidi Ernst (n 6) 310.

76 S obzirom na zahtijevani prostor potpunijeg objašnjenja, u ovoj prilici ne možemo dublje ulaziti u Ernstovu tezu o razvoju koncepta više sile od Sachbezogene do Leistungsfpflichtbezogene, već ćemo samo sumarno uputiti na bit. Glede kritike teze također vidi Gerkens (n 6) 110 i sl.

77 Prema Ernstu (n 6) 310: "Im Sprachgebrauch der Stellen, in denen die Ereignisse höherer Gewalt leistungspflichtbezogen und in einer Beziehung zum Verschuldensgedanken betrachtet werden, treten die Begriffe casus fortuitus und casus maior neben und anstelle der konkreten vis-Ereignisse. Der Kreis der Ereignisse, die als casus fortuitus bezeichnet werden, ist dabei im Grundsatz kein andere als der, die als vis maior geläufig sind. Die Verdrängung des begriffs der vis maior durch den casus fortuitus gerade in denjenigen Stellen, in denen die höhere Gewalt in Gegensatz zur culpa (oder neglegentia) bestimmt wird, zeigt aber, dass die bekannten Ereignisse, indem man vom casus fortuitus spricht, zu dem Verschuldensgedanken in Bezug gesetzt werden." 


\section{POŽAR, FORTUITUS CASUS I VIS EXTRARIA - D. 19, 2, 30, 4}

Glede odnosa casus fortuitus i vis maior u vezi s ignis i incendium smatramo da je posebno ilustrativan sljedeći slučaj koji sadržava još jedan uglavak, nešto šireg značenja, no u okviru čijeg razmatranja obuhvaćen je i problem požara u kući, izložen u D. 19, 2, 30, 4 (Alfenus 3 a Paulo epitomarum):

D. 19, 2, 30, 4 (Alfenus 3 a Paulo epitomarum) Colonus villam hac lege acceperat, "ut incorruptam redderet praeter vim et vetustatem": coloni servus villam incendit non fortuito casu. Non videri eam vim exceptam respondit nec id pactum esse, ut, si aliquis domesticus eam incendisset, ne praestaret, sed extrariam vim utrosque excipere voluisse. ${ }^{78}$

Uzimajući kao temelj djelo Alfena Vara, pretklasičnog pravnika koji je djelovao tijekom 1. st. pr. Kr. ${ }^{79}$ te koji je možda prenio mišljenje Servija, ${ }^{80}$ riječ bi bila o najranijem među tekstovima o ovoj temi. ${ }^{81}$ Uglavkom je predviđeno da zakupoprimac mora vratiti imanje u stanju u kakvom ga je primio, bez pogoršanja i oštećenja, osim ako bi ona bila posljedica više sile ili starosti, tj. propadanja zbog redovne uporabe na što kao razlog isključenja odgovornosti upućuje već i Katon u De agri cultura. ${ }^{82}$ Zakupoprimčev rob je, međutim, zapalio imanje, i to prema sačuvanom tekstu ne slučajem te je postavljeno pitanje odgovornosti za požar, je li ona obuhvaćena uglavkom ili ne. Pravnikovo je objašnjenje da se ne smatra niti je tako ugovoreno da bi bila izuzeta sila ako bi netko od članova kućanstva izazvao požar, već se htjelo izuzeti samo vanjsku silu.

Ključni problem na koji se koncentrirala većina autora jesu riječi non fortuito casu i njihov odnos prema drugoj rečenici. Naime, u prvoj rečenici bilo bi navedeno da rob nije izazvao požar slučajno, dok je u drugoj rečenici istaknut stav da se odgovara za silu, u značenju slučaja, više sile, koja bi proizašla iz sfere zakupoprimca, no ne i za onu izvana, vis extraria. Pitanje je zašto bi prvo bilo navedeno da šteta nije uzrokovana slučajno, a zatim da se odgovara za silu koja je svoje izvorište imala u okviru kućanstva.

78 D. 19, 2, 30, 4: "Kolon je primio kuću uz uglavak da je vrati neoštećenu, izuzevši štetu koja bi nastala zbog sile ili starosti. Kolonov rob je zapalio kuću, no ne nesretnim slučajem. Odgovorio je da se ne smatra da je izuzeta ona sila niti da je uglavkom izuzet od odgovornosti slučaj ako bi netko od članova kućanstva izazvao požar (zapalio kuću), već da su oba htjela izuzeti samo vanjsku silu)." Usp. Lenel (n 23) vol. I, 49.

79 Usp. Wolfgang Kunkel, Herkunft und soziale Stellung der römischen Juristen (Böhlau 1952) 29; Andreas Wacke, 'Dig. 19, 2, 33: Afrikans Verhältnis zu Julian und die Haftung für höhere Gewalt' u Hildegard Temporini (ed), Aufstieg und Niedergang der römischen Welt, vol. II (de Gruyter 1976) 458 i sl.

80 U skladu s općenitim stavom o Alfenovu zapisu Servijevih tekstova čiji je Alfen bio auditor, a s obzirom na riječ respondit, rješenje su atribuirali Serviju primjerice Mayer-Maly (n 1) 190 i Frier (n 9) 250. Suprotno stajalište, da ne postoje dostatni razlozi za tvrdnju da je rješenje Servijevo, zauzima Miglietta. Usp. Massimo Miglietta, Servius respondit (Trento 2010) 491. Von Lübtow navodi da se ne može sa sigurnošću reći tko je autor, ističući i da razlika respondi - respondit ne može biti odlučujuća jer su sigle za oboje u predjustinijanskim izvorima iste. Usp. Ulrich von Lübtow, 'Die Haftung des Pächters nach D. 19, 2, 30, 4' u Studi in onore di Emilio Betti, vol. III, (Giuffrè 1962) 369. Vidi općenitije o odnosu dva sloja epitomizirana od strane Paula te drugog anonimnog autora u: Fritz Schulz, History of Roman Legal Science (Clarendon Press 1953 [1946]) 205 i sl.; Franz Wieacker, Textstufen klassischer Juristen (Vandenhoeck \& Ruprecht 1960) 63, 84. Također o Serviju vidi Kunkel (n 79) 25; Jill Harries, Cicero and the Jurists. From Citizens' Law to the Lawful State (Duckworth 2006) 116 i sl.

81 Usp. Frier (n 9) 250.

82 Cat., De agri. 144. Također za leges locationis usp. PJ du Plessis, 'The Roman Concept of lex contractus' (2006) 3 Roman Legal Tradition 79 i sl. 
Dio autora je stoga izrazio sumnju u autentičnost verzije koja je do nas došla preko Digesta, pri čemu se može istaknuti Mayer-Malya koji smatra umetnutim dijelove non fortuito casu - exceptam te nec umjesto non, ${ }^{83}$ polazeći od toga da je tumačenjem uglavka jasno predviđena granica između sfera odgovornosti lokatora i konduktora - unutrašnje i vanjske. ${ }^{84} \mathrm{Uz}$ to možemo spomenuti i von Lübtowa s prijedlogom vrlo širokih zahvata u sam tekst, ${ }^{85}$ no koji u bitnome slijedi ovu tezu napominjući da bi požar prema prirodnom shvaćanju pripadao vanjskim okolnostima, no društveno-pravno bi se smatrao zonom kontrole i odgovornosti zakupoprimca koja je proširena samim uglavkom. ${ }^{86}$

Drugi dio romanista ipak prihvaća njegovu autentičnost, među kojima se može uputiti na Friera, Cardillija i Ferciu. ${ }^{87} \mathrm{~S}$ obzirom na to da recentnije preteže stav u korist izvornosti teksta, pobliže ćemo izložiti ključne točke izlaganja trojice navedenih autora kojima oni objašnjavaju preneseni sadržaj i funkciju non fortuito casu. Frier tako iznosi da bi non fortuito casu prema Serviju značilo da na roba nije utjecala nikakva vanjska, s ljudske strane neotklonjiva snaga, sila. ${ }^{88}$ Prema tome, umanjujući važnost suprotnosti domesticus - vis extraria, ovaj autor smatra da je u tekstu konkretnije riječ o ograničenju odgovornosti zakupoprimca, u smislu da on neće uvijek odgovarati za djelovanja vlastitih ljudi, robova, tj. kada je na njih djelovala viša sila. Cardilli pak inzistira na izvornosti izraza tumačeći da bi Alfen navedenim riječima isključio mogućnost da bi navedeno ponašanje in concreto moglo biti ocijenjeno kao casus fortuitus. ${ }^{89}$ Naime, premda je ovaj autor objašnjenja za primjenu izraza iznio u različitim formama, veći dio autorovih tumačenja, ako smo ih dobro shvatili, ${ }^{90}$ išao bi u smjeru da konkretno ponašanje u ovom slučaju ne bi bilo ocijenjeno kao slučaj te bi zbog toga potpadalo pod praestare njegova

83 U skladu s općim pristupom, Luzzatto je već ranije iznio mišljenje da je non fortuitu casu interpolirano, dok je cijeli tekst mijenjan. Mayer-Malya, čije je djelo polazište dobrog dijela novijih razmatranja te kasnije von Lübtowa, primjerice slijedi Pinna Parpaglia koji uz to stavlja pod sumnju cijeli drugi dio kao pun pleonazama i suvišnog ponavljanja. Watson uzima samo da bi bilo umetnuto non fortuito casu jer ne mijenja ništa na stvari, dok bi ostatak koji Mayer-Maly briše ostavio jer potvrđuje klasicitet teksta s obzirom na to da je u skladu s ostalim Alfenovim fragmentima. S druge strane treba spomenuti i Behrensa koji smatra da bi dio koji završava $\mathrm{s}$ casu bio točan (echt), dok nalazi nepravilnosti glede svega nakon toga. Uz uputu na daljnje autore, vidi opširnije u: Luzzatto (n 22) 222 i sl.; Behrens (n 22) 14-15; Mayer-Maly (n 1) 190; Alan Watson, The Law of Obligations in the Later Roman Republic (Clarendon Press 1984) 118; von Lübtow (n 80) 369 i sl.; Pinna Parpaglia (n 10) 72 i sl. (posebno str. 77-78). Također usp. Dieter Nörr, 'Kausalitätsprobleme im klassischen römischen Recht' u Otto Behrends et al. (eds.), Festschrift für Franz Wieacker zum 70. Geburtstag (Vandenhoeck \& Ruprecht 1978) 123 i sl.; Fritz Sturm, 'Il pactum e le sue molteplici applicazioni' u Francesco Milazzo (ed), Contractus e Pactum. Tipicità e libertà negoziale nell'esperienza tardo-repubblicana (Edizioni Scientifiche Italiane 1990) 169.

84 Bit obrazloženja sadržaja teksta nakon odstranjivanja interpolacije bila bi u tome da bi svako uzrokovanje štete koje nije učinjeno od strane trećih ili prirodnim silama bilo obuhvaćeno uglavkom. Usp. Mayer-Maly (n 1) 190.

85 Prema njegovoj rekonstrukciji tekst bi glasio: "Colonus - incendit [non fortuito casu]: extraneam vim exceptam videri respondit, ut (so dass), si aliquis domesticus villam incendisset, colonum damnum praestare debeat." Usp. von Lübtow (n 80) 373.

86 Ibid 372.

87 Uz njih možemo spomenuti i Hoffmann-Riema, Knütela, Molnára, Robayea, Fiorija i Capogrossi Colognesija koji uzimaju tekst kao izvorno sačuvan, dok bismo za cjelokupni pregled pristalica izvornosti, kao i suprotnog stava, uputili na Fercia (n 9) 92, bilj. 26. Usp. Wolfgang Hoffmann-Riem, 'Die Custodia-Haftung des Sachmieters untersucht an Alf./Paul. D. 19,2,30,2' (1969) 86 SZ RA 394 i sl.; Frier (n 9) 250 i sl.; Knütel (n 16) 365; Molnár (n 10) 628 i sl.; Robaye (n 18) 404; Cardilli (n 10) 257 i sl.; Fiori (n 10) 86 i sl. (posebno str. 87, bilj. 82); Capogrossi Colognesi (n 10) 30 i sl.; Fercia (n 9 ) 92 i sl. 
gospodara, ${ }^{91,92}$ iako bi se prema određenim tvrdnjama moglo zaključiti i da bi sva ponašanja članova domaćinstva pripadala sferi odgovornosti zakupoprimca. ${ }^{93} \mathrm{U}$ potonjem smislu, pozivajući se na Knütela i njegovo sumarno objašnjenje odgovornosti kao Garantiehaftung ${ }^{94}$ za sve okolnosti koje ne pripadaju u vis extraria,${ }^{95,96}$ početno se izjašnjava i Fercia. ${ }^{97}$ Međutim, Fercia je ipak detaljnije pojasnio problem odnosa dviju rečenica naglašavajući da je za odgovornost zakupoprimca ključno da su ispunjena oba elementa - i da rob nije uzrokovao požar fortuito casu i da se to ponašanje (evidentemente riprovevole) može pripisati članu kućanstva (domesticus) ${ }^{98}$ Ako jedan od dvaju elemenata ne bi bio ispunjen, bila bi riječ o vis extraria te zakupoprimac ne bi odgovarao, čime je zapravo reafirmirana Frierova teza o funkciji non fortuito casu u tekstu. Kao dokaz u navedenom smjeru Fercia upućuje i na sličnost dijalektike odnosa incendere villam - non fortuito casu te vis extraria - aliquis domesticus. ${ }^{99}$

Uzimajući u obzir izložene argumente obje skupine autora možemo se vratiti na početno pitanje o odnosu tvrdnje iz prve rečenice da šteta nije uzrokovana slučajno te odgovora iz

91 U okviru analize fragmenta izdvojili bismo dva mjesta na kojima se Cardilli najjasnije izjašnjava o funkciji non fortuitu casu. Prva je, donekle općenitije naravi, no s umetkom "nell'ipotesi esaminata", kod iznošenja opće Alfenove argumentacije: "La possibilità di imputare l'inadempimento al colono viene motivata attraverso due spiegazioni che si intersecano tra loro. La prima, di natura puramente logico-concettuale, nega che l'incendio dello schiavo possa considerarsi, nell'ipotesi esaminata, 'caso fortuito', possa cioè essere la vis excepta, coerentemente al concetto di vis che Servio aveva formulato in L. 15,2 (D. 19.2.), come "forza esterna ed irresistibile." (str. 259). Druga, konkretnija uputa bi bila: "Ciò è la prova che il giurista negasse al fatto la qualifica di fortuito ed esprimesse un giudizio riprovevole sul comportamento del servo." (str. 260). Usp. Cardilli (n 10) 259-260. Slično tome se izjašnjava i Fiori polazeći od toga da kolon odgovara za djelovanje svoga roba, posebno jer njegovo ponašanje nije bilo rezultat više sile, koncentrirajući se u prvom dijelu na otklonjivost sile, a u drugom na vanjsku narav kao dva odvojena elementa. Navedeno je vidljivo iz: "il damnum è addebitato al colono perché l'incendio si e realizzato non fortuito casu." Usp. Fiori (n 10) 87 - 88. Također se slično razmišljanje može razaznati iz Ernstova kratkog komentara u fusnoti uz D. 19, 2, 30, 4 - "vis extraria im Gegensatz zu einem Verschulden Hausangehöriger". Usp. Ernst (n 6) 372, bilj. 44.

92 Iako Pinna Parpaglia polazi od šireg opsega interpolacija, ovaj autor iznosi dosta slična razmišljanja smatrajući da je ovdje riječ o odgovornosti kolona za odgovarajuću obradu zemlje. U tom smislu možemo citirati: “... ma rispondesse lui, il colono, per i danni provocati dalla sua incapacità o negligenza dello svolgere la sua opera. Giacché la oculata scelta dei propri collaboratori nessuno verrà negare che rientri nella sfera delle capacità professionali del buon coltivatore" (str. 79), kao i "mi sembra, infatti, che la precauzioni necessarie nell'uso del fuoco per le varie esigenze della campagna, più che da obblighi di custodia nei confronti del campo o della villa, siano anzitutto dettate della perizia e dalla pratica della buona coltivazione, nel senso appena chiarito" (str. 80). Usp. Pinna Parpaglia (n 10) 78 i sl.

93 Mješovito značenje imala bi rečenica u kojoj autor ističe da obveza proizlazi iz lex locationis, no dodajući da vatra nije zapaljena slučajem ("ed in particolare se una volta propagatosi il fuoco acceso non casualmente dal servus, e incendiata la villa, ciò fosse o meno da porre a carico del colono."). U prvom redu tu se može navesti iz zaključnog odjeljka analize fragmenta sljedeća rečenica, u kojoj se u riječima tanto più vidi taj, nešto drukčiji pristup: "La vis excepta sarebbe, anche per le parti contraenti, solo quella extraria, venendosi a contrapporre un 'ambito domesticus' ad un 'ambito esternò nella provenienza dell'incendio: tutto ciò che, proveniente dal primo, tanto più se non accidentale, deteriori la cosa da restituire, condizionerà il riconoscimento del praestare del colono." Usp. Cardilli (n 10) 260-261.

94 Premda treba dodati da se Knütelovo objašnjenje podudara s već ranije iznesenom tezom o Garantiepflicht kod Mayer-Malya, iako je Mayer-Maly brisao non fortuito casu. Usp. Mayer-Maly (n 1) 190; Knütel (n 16) 365.

95 Usp. Knütel (n 16) 365.

96 Pritom se možemo osvrnuti i na Capogrossi Colognesija prema kojemu uglavak nije u bitnome promijenio prava i obveze stranaka jer bi zakupoprimac i inače odgovarao za osobe koje pripadaju njegovoj sferi kontrole, odnosno dolozno paljenje vatre od strane roba, kako ga ocjenjuje, nije "estraneo all evento dannoso" (str. 31). Kritiku navedenog stava iznosi Fercia inzistirajući na proširenju odgovornosti kolona uglavkom. U tom elementu pristalice autentičnosti iznose sličan stav poput kritičara, a slično se može zaključiti i prema Molnárovoj tvrdnji da je uglavkom proširena odgovornost na casus minor (iako, treba primijetiti, izraz se tu uopće ne koristi, a i Kaser općenito navodi da bi bio unrömisch (Kaser, RPR I, str. 512)). Pritom Molnár ističe, prateći Watsonovu argumentaciju (Watson (n 83) 121), da bi bila riječ o vremenu u kojem se još nije probila odgovornost za kustodiju te su stoga stranke navedeno i uključile u ugovor. Usp. Molnár (n 10) 629; Capogrossi Colognesi (n 10) 31-32; Fercia (n 9) 94. Usp. Fercia (n 9) 94.

98 U vezi s drugom rečenicom tako iznosi da bi djelovanje roba bilo "vis interna alla gestione della villa". Ibid 95-96. 
druge rečenice o priznanju izuzeća od odgovornosti samo glede vanjske sile. Bliži smo pritom naporima i obrazloženjima kojima bi se tekst objasnio u obliku prenesenom u Digestama te se u određenoj mjeri možemo složiti s tezom o potrebi kumulativnog ispunjenja dviju pretpostavki (non fortuito casu i domesticus) kako ju iznosi Fercia. Smatramo, međutim, da u navedenim obrazloženjima nije odgovarajuće vrednovana razlika i odnos ignis i incendium, odnosno činjenica da se upravo incendium navodi u katalozima oblika više sile pretklasičnih i klasičnih pravnika. Naime, u ključnom dijelu druge rečenice Non videri eam vim exceptam respondit nec id pactum esse, napose riječima eam vim a u vezi sa si aliquis domesticus eam incendisset, vjerujemo da je pravnik, Alfen ili Servije, mislio na požar, a moguće i neki drugi oblik više sile koji je mogao nastati i iz ljudskog djelovanja, no ne i na svaku drugu višu silu, poput oluje, potresa i slično. ${ }^{100}$ Kao što se može vidjeti iz drugih tekstova koji su izneseni ranije u radu, početno u D. 19, 2, 9, 3, u situacijama kada je trebalo odlučiti odgovara li zakupoprimac za štetu od požara odlučuje se u dva stupnja, odnosno pojavljuju se dva kriterija - je li zakupoprimcu uopće bilo dopušteno držati vatru ili lako zapaljivi materijal te kako je od obične vatre nastao požar, krivnjom zakupoprimca ili višom silom. Ako držanje vatre nije bilo dopušteno, no zakupoprimac ju je držao te je buknuo požar, nije bilo bitno je li on bio kriv ili ne te je odgovarao. S druge strane, ako mu je to bilo dopušteno, odnosno nije bilo zabranjeno držati vatru, on bi odgovarao samo ako požar ne bi nastao fortuito casu. U skladu s navedenim, smatramo da bi tekst bio izvorno prenesen, pri čemu bi non fortuito casu kvalificiralo nastanak požara (incendium) kao jednog oblika vis maior za koji se uobičajeno ne bi odgovaralo, no ako je požar nastao namjerno ili nepažnjom, tada bi.

Stoga bi se moglo ustvrditi, u skladu s onime što iznosi i Frier, ${ }^{101}$ da bi u slučaju da je na robove, ili primjerice na postojeću vatru na ognjištu, djelovala vis extraria, primjerice olujni vjetar ili potres, ili bi požar nastao zbog udara groma kao vis extraria, tada zakupoprimac ne bi odgovarao za štetu zbog toga što nije mogao vratiti kuću (villa) u stanju u kakvom ju je dobio. U vezi s navedenim djelovanjem vanjske sile, posebno vjetra koji bi bio relevantan za rasplamsavanje vatre, možemo uputiti i na D. 39, 2, 43 pr. (Alfenus libro secundo digestorum), odnosno D. 39, 2, 24, 4 (Ulpianus 81 ad edictum), prema kojima bi upravo Servije dao odgovor da vlasnik neće odgovarati iz cautio damni infecti ako je jak vjetar, definiran kao vis divina, skinuo crijepove i nanio štetu na susjedovu krovu. ${ }^{102} \mathrm{Na}$ isti način, uzimanjem u obzir ovog Servijeva rješenja, doista bi teško bilo prihvatiti da bi sam Servije ili Alfen kao njegov učenik, prihvatili da zakupoprimac odgovara za štetu koja bi nastala djelovanjem više sile na robovo ponašanje ili na vatru koju je potpalio, tj. da bi odgovarao za svaki požar te je zato i navedeno non fortuito casu. Također, ovim navodom u prvoj rečenici može se objasniti i izostanak kvalifikacije incendisset u drugoj jer bi doista bila riječ o nepotrebnom ponavljanju.

\footnotetext{
100 Tu možemo dodati i Nörrovo tumačenje da bi samo riječ vis ovdje imala tehničko značenje, dok vis extraria to ne bi imala ("Dem späteren Terminus vis maior entspricht hier vis allein."). Usp. Nörr (n 83) 123.

101 Usp. Frier (n 9) 251-252.

102 Vidi Mayer-Maly (n 6) 61.
} 


\section{ZAKLJUČAK}

$\mathrm{Na}$ temelju analize tekstova izloženih u radu pokušalo se odgovoriti na osnovno pitanje o izvornom sadržaju paragrafa D. 19, 2, 9, 3 te u vezi s time analizirati položaj rizika nastanka požara kod ugovora o zakupu. Kao što je početno navedeno, periculum se unutar titula o locatio conductio spominje u prvom redu u vezi s locatio conductio operis i to u situacijama kada je rizik slučajne propasti stvari prelazio na konduktora. U vezi s locatio conductio rei, periculum se izričito javlja kod najma skladišta i odgovornosti za stvari unesene na čuvanje, a glede zakupa zemljišta tek u D. 19, 2, 9, 3. Općenito, rizik slučajne propasti ili oštećenja predmeta zakupa zbog kojega ne bi više bilo moguće ostvariti svrhu ugovora, u prvom redu za zakupoprimca onemogućavanjem uti i frui, bio je raspravljen u nizu tekstova pravnika, među kojima je najpoznatiji D. 19, 2, 15, 2 koji je već ranije šire analiziran. Princip od kojega su pravnici polazili jest da je opasnost štete zbog više sile, koja je generalno u izvorima (također) obuhvaćena pojmom periculum, teretila zakupodavca, što se ponajprije objašnjava time da je on bio vlasnik stvari. Unatoč tome, zakupodavac je mogao ugovorom, odnosno posebnom klauzulom u ugovoru, prebaciti rizik više sile, ili općenito kao u D. 19, 2, 9, 2, ili posebnih pojavnih oblika više sile koji su učestalije prijetili imanju kao što je bio slučaj s požarom, na kojeg upućuju D. 19, 2, 9, 3 ili D. 19, 2, 11, 4, na drugu stranu.

Glede potonje prakse i sadržaja lex locationis postoji bitna razlika između slučajeva navedenih u D. 19, 2, 9, 3 i u D. 19, 2, 11, 1. U prvom slučaju predviđeno je prebacivanja rizika štete od požara samo u slučaju požara koji nije nastao iz "bezopasnog" plamena, dok se u drugom to odnosilo na bilo kakvu vatru. Smatramo da je ta razlika ključna u pogledu dvojbi o sadržaju D. 19, 2, 9, 3 te da je isticanje načina razvoja požara u paragrafu važan argument u korist vulgatnog čitanja toga teksta. Naime, u slučaju apsolutne zabrane paljenja vatre zakupoprimac bi odgovarao za bilo koji požar, bez obzira na način nastanka, dok bi u D. 19, 2, 9, 3 odgovarao za slučajan nastanak požara samo ako plamen nije bio bezopasan, ali ako je držana "sigurna" vatra, ne bi odgovarao za fortuitus casus, već samo za krivnju u skladu s općim pravilima. Svijest o tome da je požar mogao nastati iz ljudskog djelovanja namjerno ili slučajno, kako prenosi Gaj u D. 47, 9, 9, već je i ranije bila prisutna kod Rimljana. U skladu s navedenim, logično bi bilo da je i pri određenju kontraktne odgovornosti kod zakupa, glede požara (incendium), pojavno jednog od oblika više sile, bilo moguće i potrebno odrediti bi li njegov nastanak bio pripisiv jednoj od stranaka, uvažavajući pritom i nepažnju (culpa, neglegentia) kao temelj odgovornosti, ili to ne bi bio.

Riječima (non) fortuito casu tako bi i u D. 19, 2, 9, 3, D. 19, 2, 11, 1 te u D. 19, 2, 30, 4 bilo precizirano na koji je način požar nastao, odnosno je li razlog njegova nastanka bio u sferi rizika (ako je bilo zabranjeno držati vatru ili sijeno, a nije se ponašao u skladu s ugovorom, odgovara i za štetu nastalu fortuito casu) i odgovornosti zakupoprimca (ako se ponašao u skladu s uglavkom, ne odgovara za slučajni razvoj požara i štetu uzrokovanu njime, nego samo ako je bio kriv za njegov nastanak), ili bi štetu od požara, kao jednog od oblika više sile, kao vis cui non resistit, morao snositi zakupodavac. Uputom na odnos zakupoprimca i njemu podčinjenih osoba prema razvoju požara iz vatre koju su držali, kvalifikacijom (non) fortuitu casu, bila bi ograničena njegova ugovorno predviđena odgovornost, pri čemu smatramo bi se njezina funkcija mogla tumačiti u smislu evolucije shvaćanja više sile s obzirom na obveznu činidbu, međutim, već bi i sama praksa ugovaranja lex locationis čiji je smisao bio prebaciti rizik slučajne propasti 
na drugu stranu upućivala na višu silu kao razlog oslobođenja od odgovornosti. Diferencirani pristup požaru i posljedičnim štetama kod ugovora o zakupu tako pokazuje svoju važnost i samostalno u vezi s praktičnim rješenjima izmjene granica ugovornih obveza stranaka, ali i u širem kontekstu omogućavajući nijansiraniji pristup daljnjoj obradi problema razvoja više sile.

\section{BIBLIOGRAFIJA}

1. Aličić S, Imovinska šteta u rimskom klasičnom pravu (University Press 2017)

2. Arangio-Ruiz V, Istituzioni di diritto romano (14th ed., Jovene, 1960)

3. Arangio-Ruiz V, Responsabilità Contrattuale in Diritto Romano (2nd ed., Jovene 1933)

4. Behrens D, Die vis maior und das klassische Haftungssystem (DPhil thesis, Giessen 1936)

5. Berger A, Encyclopedic Dictionary of Roman Law (The American Philosophical Society 1980 [1953])

6. Betti E, 'Periculum". Problema del rischio contrattuale in diritto romano classico e giustianeo' u Studi in onore di Pietro de Francisci, vol. I, (Giuffrè, 1956) 131

7. Betti E, 'Zum Problem der Gefahrtragung bei zweiseitig verpflichtenden Verträgen' (1965) 82 Zeitschrift der Savigny-Stiftung für Rechtsgeschichte. Romanistische Abteilung 1

8. Birks N, 'Cooking the Meat: Aquilian Liability for Hearths and Ovens' (1985) 20(2) Irish Jurist 352

9. Cannata CA, Sul problema della responsabilità nel diritto privato romano (Libreria Editrice Torre 1996)

10. Canter HV, 'Conflagrations in Ancient Rome' (1932) 27(4) The Classical Journal 270

11. Capogrossi Colognesi L, Remissio mercedis. Una storia tra logiche di sistema e autorità della norma (Jovene 2005)

12. Cardilli R, L'obbligazione di "praestare" e la responsabilità contrattuale in diritto romano (II sec. A.C. - II sec. D.C.) (Giuffrè 1995)

13. Cursi MF, 'The Scope and Function of Civil Wrongs in Roman Society' u du Plessis PJ, Ando C and Tuori K (eds), The Oxford Handbook of Roman Law and Society (Oxford University Press 2016) 596.

14. Daube D, 'Nocere and noxa' (1939) 7 Cambridge Law Journal, 23 u Daube D, Collected studies in Roman Law, I., (Vittorio Klostermann 1991)

15. Daube D, 'On the Third Chapter of the lex Aquilia' (1936) 52 Law Quarterly Review 253 u Daube D, Collected studies in Roman Law, I., (Vittorio Klostermann 1991)

16. De Medio A, 'Caso fortuito e forza maggiore in diritto romano' (1908) 20 Bullettino dell'Istituto di diritto romano 157

17. de Neeve PW, 'Remissio mercedis' (1983) 100 Zeitschrift der Savigny-Stiftung für Rechtsgeschichte. Romanistische Abteilung, 296

18. Divković M, Latinsko-hrvatski rječnik (Dunja 2006[1900])

19. du Plessis JP, A History of remissio mercedis and related legal institutions (DPhil thesis Rotterdam, 2003)

20. du Plessis JP, Letting and Hiring in Roman Legal Thought: 27 BCE - 284 CE (Brill 2012)

21. du Plessis JP, ‘The Roman Concept of lex contractus' (2006) 3 Roman Legal Tradition 79-94.

22. du Plessis P, 'Liability', 'risk' and locatio conductio' u Fiori R (ed), Modelli teorici e metodologici nella storia del diritto privato, vol. IV (Jovene 2011) 63 
23. du Plessis P, 'Notes on a fire' u Sturm F, Philip T and Jochen O (eds), Liber Amicorum Guido Tsuno (Vico 2013) 277

24. Ernout A i Meillet A, Dictionnaire étymologique de la lingue latine (Klincksieck 2001)

25. Ernst W, 'Das Nutzungsrisiko bei der Pacht' (1988) 105 Zeitschrift der Savigny-Stiftung für Rechtsgeschichte. Romanistische Abteilung 541

26. Ernst W, 'Wandlungen des 'vis maior'-Begriffes in der Entwicklung der römischen Rechtswissenschaft' (1994) 22 Index. Quaderni camerti di studi romanistici 293

27. Fercia R, La responsabilità per fatto di ausiliari nel diritto romano (CEDAM 2008)

28. Fiori R, 'Bona fides', u Fiori R (ed), Modelli teorici e metodologici nella storia del diritto privato, vol. IV (Jovene 2011) 97

29. Fiori R, La Definizione dell 'locatio conductio', Giurisprudenza romana e tradizione romanistica (Jovene 1999)

30. Frier BW, Landlords and Tenants in Imperial Rome (Princeton University Press 1980)

31. Frier BW, 'Law, Economics, and Disasters Down on the Farm: 'Remissio Mercedis' Revisited' (19891990) 31-32 Bullettino dell'Istituto di diritto romano 237

32. Frier BW, 'Tenant's Liability for Damage to Landlord's Property in Classical Roman Law' (1978) 95 Zeitschrift der Savigny-Stiftung für Rechtsgeschichte. Romanistische Abteilung 232

33. Gerkens J-F, "'Vis maior" and "vis cui resisti non potest"' u van den Bergh Ri van Niekerk G (ed), Ex iusta causa traditum. Essays in honour of Eric H. Pool (University of South Africa 2005) 109

34. Von Glück CF, Ausführliche Erläuterung der Pandecten nach Hellfeld: ein Commentar, (Erlangen 1815)

35. Guarino A, Diritto privato romano (12th edition, Jovene 2001.

36. Harke JD, Locatio conductio, Kolonat, Pacht, Landpacht (Duncker \& Humblot 2005)

37. Harries J, Cicero and the Jurists. From Citizens' Law to the Lawful State (Duckworth 2006)

38. Hausmaninger H, Das Schadenersatzrecht der lex Aquilia (5. Aufl., Manzsche Verlags- und Universitätsbuchhandlung 1996)

39. Haymann F, 'Textkritische Studien zum römischen Obligationenrecht' (1919) 40 Zeitschrift der Savigny-Stiftung für Rechtsgeschichte. Romanistische Abteilung 167

40. Heimbach GE i Heimbach CGE Basilicorum libri LX, vol. II, (Lipsiae 1840)

41. Hoffmann-Riem W, 'Die Custodia-Haftung des Sachmieters untersucht an Alf./Paul. D. 19,2,30,2' (1969) 86 Zeitschrift der Savigny-Stiftung für Rechtsgeschichte. Romanistische Abteilung 394

42. Horvat M, Rimsko pravo (Pravni fakultet Sveučilišta u Zagrebu 2017)

43. Karlović T, Liber casuum. Priručnik za vježbe iz rimskog obveznog prava (Pravni fakultet u Zagrebu 2017)

44. Karlović T i Balić A, Remissio mercedis i utjecaj promijenjenih okolnosti na obveze iz ugovora o zakupu u rimskom pravu, (2020) 57(4) Zbornik Pravnog fakulteta u Splitu 957

45. Kaser M, Das römische Privatrecht, I, Das altrömische, das vorklassische und klassische Recht (2. Aufl., Beck'sche Verlagsbuchhandlung 1971)

46. Kaser M, 'Periculum locatoris' (1957) 74 Zeitschrift der Savigny-Stiftung für Rechtsgeschichte. Romanistische Abteilung 155

47. Katančević A, 'Vis maior i locatio conductio fundi' (2013) 61(2) Anali Pravnog fakulteta u Beogradu 215

48. Kehoe DP, Investment, Profit, and Tenancy. The Jurists and the Roman Agrarian Economy (The University of Michigan Press 1997) 
49. Kehoe DP, 'Tenure of Land and Agricultural Regulation' u du Plessis PJ, Ando C i Tuori K (eds), The Oxford Handbook of Roman Law and Society (Oxford University Press 2016) 646

50. Kehoe D, Law and Rural Economy in the Roman Empire (The University of Michigan Press 2007)

51. Kleinfeller G, 'Incendium' u Paulys Realencyclopädie der classischen Altertumswissenschaft, IX, 2 (Halbband 18) (Mezler 1918) 1244

52. Knütel R, 'Die Haftung für Hilfspersonen im römischen Recht' (1983) 100 Zeitschrift der Savigny-Stiftung für Rechtsgeschichte. Romanistische Abteilung 340

53. Kołodko P, 'The Powers and Significance of the Prefect of the 'Vigiles' ('praefectus vigilum') in Ancient Rome' (2012) 12(4) Zeszyty Prawnicze 199

54. Kunkel W, Herkunft und soziale Stellung der römischen Juristen (Böhlau 1952)

55. Lenel O, Palingenesia Iuris Civilis, vol. I i II, (Vico, 2006 [1889])

56. Liebs D, Die Klagenkonkurrenz im römischen Recht (Vandenhoeck \& Ruprecht, Göttingen, 1972)

57. Luzzatto GI, Caso fortuito e forza maggiore come limite alla responsabilità contrattuale, vol. I (Giuffrè 1938)

58. MacCormack G, 'Aquilian Culpa' u Watson A (ed), Daube noster: Essays in Legal History for David Daube (Scottish Academic Press 1974) 201

59. MacCormack G, 'Criminal Liability for Fire in Early and Classical Roman Law' (1972) 3 Index. Quaderni camerti di studi romanistici 382

60. MacCormack G, 'Culpa in eligendo' (1971) 18 Revue internationale des droits de l'antiquité 525

61. MacCormack G, 'Fault and Causation in Early Roman Law: An Anthropological Perspective' (1981) 28 Revue internationale des droits de l'antiquité 97

62. MacCormack G, 'Periculum' (1979) 96 Zeitschrift der Savigny-Stiftung für Rechtsgeschichte. Romanistische Abteilung 129

63. Martin S, 'The Case of the Collapsing Watercourse: Builders' Responsibility for Damage in Classical Roman Law' (1986) 4(2) Law and History Review 423

64. Masi A, Il problema della remissione della mercede nella locazione di fundi rustici all luce di una testimonianza di Columella, u Studi in memoria di Giuliana D’Amelio, vol. I, (Giuffrè 1978) 273

65. Mayer-Maly T, 'Höhere Gewalt: Falltypen und Begriffsbildung' u Festschrift für Arthur Steinwenter zum 70. Geburtstag (Böhlau 1958) 58

66. Mayer-Maly T, Locatio conductio (Verlag Herold 1956)

67. Miglietta M, Servius respondit (Trento 2010)

68. Minieri L, 'Normative Antincendio in Diritto Romano Tardo Classico e Postclassico' (2004) 1(13) IVS ANTIQVVM, Drevnee pravo, 83

69. Minieri L, 'Sul quasi incendiarius' (2011) 58 Revue internationale des droits de l'antiquité 250

70. Miquel J, 'Periculum locatoris' (1964) 81 Zeitschrift der Savigny-Stiftung für Rechtsgeschichte. Romanistische Abteilung 134

71. Molnár I, 'Verantwortung und Gefahrtragung bei der locatio conductio zur Zeit des Prinzipats' u Temporini H i Haase W (eds), Aufstieg und Niedergang der römischen Welt, vol. II, 14 (de Gruyter 1982) 583

72. Müller CH, Gefahrtragung bei der locatio conductio. Miete, Pacht, Dienst- und Werkvertrag im Kommentar römischer Juristen (Schöningh 2002)

73. Nörr D, 'Kausalitätsprobleme im klassischen römischen Recht' u Behrends O et al. (eds), Festschrift für Franz Wieacker zum 70. Geburtstag (Vandenhoeck \& Ruprecht 1978) 115 
74. Nörr D, rec. Festschrift für Arthur Steinwenter zum 70. Geburtstag, Böhlau, Graz, 1958., (1959) 76 Zeitschrift der Savigny-Stiftung für Rechtsgeschichte. Romanistische Abteilung 633

75. Palazzolo N, Saggi in materia di locazione (Libreria Editrice Torre 1995)

76. Pelloso C, 'Custodia, receptum e responsabilità contrattuale' (2016) 29 Seminarios Complutenses de Derecho Romano 263

77. Pflüger HH, Zur Lehre von der Haftung des Schuldners nach römischem Recht (1947) 65 Zeitschrift der Savigny-Stiftung für Rechtsgeschichte. Romanistische Abteilung 121

78. Pichonnaz P, 'De la "clausula rebus sic stantibus" au "hardship". Aspects d'une évolution du rôle du juge' u Ruelle A i Berlingin M (ed), Le droit romain d'hier á aujourd 'hui. Collationes et oblationes. Liber amicorum en l'honneur du professeur Gilbert Hanard (Saint Louis 2009) 149

79. Pichonnaz P, Les fondements romains du droit privé (Schulthess 2008)

80. Pinna Parpaglia P, Vitia ex ipsa re. Aspetti della locazione in diritto romano (Giuffrè 1983)

81. Purcell N, 'The Roman villa and the landscape od production' u Cornell TJ i Lomas K (eds) Urban Society in Roman Italy (Routledge 1996) 157

82. Rainbird JS, The Vigiles of Rome (DPhil thesis, Durham University 1976) dostupno na: <http://etheses.dur.ac.uk/7455/> pristupljeno 25. siječnja 2021.

83. Robaye R, L'obligation de garde. Essai sur la responsabilité contractuelle en droit romain (Publications des Facultés Universitaires Saint-Louis 1987)

84. Robinson OF, Ancient Rome: City Planning and Administration (Routledge 1994)

85. Robinson O, 'Fire prevention at Rome' (1977) 24 Revue internationale des droits de l'antiquite 377

86. Romac A, Rimsko pravo (Narodne novine 1994)

87. Rossetti R, Alle origini della moderna responsabilità extracontrattuale. L'actio ex lege Aquilia tra "natura penale" e "funzione reipersecutoria", Forum historiae iuris, 22. Mai 2020, dostupno na: https://forhistiur.net/2020-05-rossetti/ pristupljeno 26. siječnja 2021.

88. Sablayrolles R, Libertinus miles. Les cohortes de vigiles (École Française de Rome 1996)

89. Schulz F, 'Die Haftung für das Verschulden der Angestellten im klassischen römischen Recht' (1911) 38 Grünhuts Zeitschrift 9

90. Schulz F, History of Roman Legal Science (Clarendon Press 1953 [1946])

91. Sirks AJB, 'Delicts' u Johnston D (ed) The Cambridge Companion to Roman Law (Cambridge University Press 2015) 246

92. Sitek B, 'Criminal Liability of 'incendiarii' in Ancient Rome' (2007) 6 Diritto e Storia dostupno na: <http://www.dirittoestoria.it/6/Rassegne/Sitek-Incendiarii-ancient-Roman-Law.htm> pristupljeno 25. siječnja 2021.

93. Sitzia F, 'Considerazioni in tema di periculum locatoris e di remissio mercedis' u Studi in memoria di Giuliana D’Amelio, vol. I (Giuffrè 1978) 331

94. Sturm F, 'Il pactum e le sue molteplici applicazioni' u Milazzo F (ed) Contractus e Pactum. Tipicità e libertà negoziale nell'esperienza tardo-repubblicana (Edizioni Scientifiche Italiane 1990) 149

95. Talamanca M, Istituzioni di diritto romano (14th ed., Giuffrè 1990)

96. Thomas JAC, 'Actiones ex locato/conducto and Aquilian Liability' (1978) 20 Acta Juridica 127

97. Thomas JAC, 'Digest 19.2.9.3' (1962) 79 Zeitschrift der Savigny-Stiftung für Rechtsgeschichte: Romanistische Abteilung 334

98. von Lübtow U, 'Die Haftung des Pächters nach D. 19, 2, 30, 4' u Studi in onore di Emilio Betti, vol. III (Giuffrè 1962) 367 
99. Wacke A, 'Dig. 19, 2, 33: Afrikans Verhältnis zu Julian und die Haftung für höhere Gewalt' u Temporini $\mathrm{H}$ (ed) Aufstieg und Niedergang der römischen Welt, vol. II (de Gruyter 1976) 455

100. Watson A, The Law of Obligations in the Later Roman Republic (Clarendon Press 1984)

101. Wieacker F, Textstufen klassischer Juristen (Vandenhoeck \& Ruprecht 1960)

102. Zimmermann R, The Law of Obligations: Roman Foundations of the Civilian Tradition (Oxford University Press 1992) 
Tomislav Karlovic**

\section{IGNIS, INCENDIUM, FORTUITUS CASUS - D. 19, 2, 9, 3 AND THE RISK OF FIRE IN LOCATIO FUNDI}

\section{Summary}

The paper discusses the issues of the contents and the significance of Ulpian's text D. 19, 2, 9, 3 within a wider context of allocation of risk in lease agreements and the place of fire, conflagration (incendium) among the different forms of vis maior in Roman legal sources. Considering the problem of subsequent impossibility of performance in locatio conductio (rei), D. 19, 2, 9, 3 stands out as the one mentioning periculum in relation to locatio fundi, however, it is burdened by different interpretations. The analysis in the article starts with the D. 19, 2, 9, 3 and then continues setting it in the context of other related texts in which the Roman jurists dealt with the problem of fire in lease agreements. The conclusion is drawn on the probable changes in the text as well as on the function of the term fortuitus casus in the line of the texts dealing with fire. It emphasizes the connection between fire (ignis) and conflagration (incendium) marked by the words fortuitus casus, which would show a differentiated approach to incendium as a form and an example of vis maior.

Keywords: $\quad$ ignis, incendium, fortuitus casus, vis maior, locatio conductio, fire 
